\title{
Synthesis, molecular docking, and preliminary cytotoxicity study of some novel 2-(naphthalen-1-yl)-methylimidazo[2,1-b][1,3,4]thiadiazoles
}

\author{
Choodamani B* *Equal first author ${ }^{\mathrm{a}}$, Sujeet Kumar* Ph D *Equal first author ${ }^{\mathrm{a}}$, Alok Kumar Gupta ${ }^{\mathrm{a}}$, \\ Dominique Schols $\mathrm{Ph} \mathrm{D}^{\mathrm{b}}$, Hakan Tahtaci Ph $\mathrm{D}^{\mathrm{c}}$, Tuncay Karakurt Ph $\mathrm{D}^{\mathrm{d}}$, Satvik Kotha ${ }^{\mathrm{e}}$, Swapna $\mathrm{B}^{\mathrm{e}}$, \\ Ramachandra Setty $\mathrm{Ph} \mathrm{D}^{\mathrm{e}}$, Subhas S. Karki** Ph D **Corresponding author ${ }^{\mathrm{a}, *}$ \\ ${ }^{a}$ Department of Pharmaceutical Chemistry, Dr. Prabhakar B. Kore Basic Science Research Center, Off-Campus, KLE College of Pharmacy, (A Constituent Unit of KAHER-Belagavi) Bengaluru \\ 560010, Karnataka, India \\ ${ }^{\mathrm{b}}$ Rega Institute for Medical Research, Department of Microbiology, Immunology and Transplantation, Laboratory of Virology and Chemotherapy, KU Leuven, B-3000 Leuven, Belgium \\ ${ }^{\mathrm{c}}$ Department of Chemistry, Faculty of Science, Karabuk University, 78050, Karabuk, Turkey \\ ${ }^{\mathrm{d}}$ Department of Chemical Engineering, Faculty of Engineering and Architecture, Kurşehir Ahi Evran University, 40100, Kurşehir, Turkey \\ ${ }^{\mathrm{e}}$ Department of Pharmacology, Government College of Pharmacy, Bengaluru 560027, Karnataka, India
}

\section{ART ICLE INFO}

\section{Article history:}

Received 15 September 2020

Received in revised form 3 January 2021

Accepted 12 February 2021

Available online $\mathrm{xxx}$

\section{Keywords}

Imidazo[2,1-b][1,3,4] thiadiazole

ADME

Molecular docking

Cytotoxicity

Levamisole

Melphalan

Molecular dynamics

\begin{abstract}
A B S T R A C T
A series of 2-(naphthalen-1-yl)-methyl-6-arylimidazo[2,1-b][1,3,4] thiadiazole derivatives was prepared and studied for cytotoxicity against murine leukemia L1210, human cervix carcinoma HeLa, and human T-lymphocyte CEM cell lines. The preliminary study showed that compounds $5 \mathrm{~g}, 6 \mathrm{~g}, 7 \mathrm{a}-\mathrm{c}, 7 \mathrm{e}$, and $8 \mathrm{e}$ were more potent among the tested compounds. The pharmacokinetic properties of all compounds were then investigated with FAF-Drugs, a tool for prediction of ADME and toxicity. Finally, in order to support in vitro studies, molecular docking studies were performed by using AutoDock Vina with a Lamarckian genetic algorithm to determine whether or not the synthesized compounds could be used as inhibitors for the protein structure $1 \mathrm{~m} 17$ (EGFR). The docking scores of many compounds were found to be higher than [6,7-bis(2-methoxy-ethoxy)quinazoline-4-yl]-(3-ethynyl phenyl)amine, an inhibitor of the $1 \mathrm{~m} 17$ EGFR receptor. Among the selected compounds $\mathbf{7 b}, \mathbf{7 c}, \mathbf{7 e}, \mathbf{7 f}, \mathbf{7 g}$, and $\mathbf{8 g}$ showed better stability in the molecular dynamics simulation study.
\end{abstract}

\section{Introduction}

Cancer is a large group of diseases and can start in any tissue or organ. Cancer worldwide is the second leading cause of death, after heart disease, and is estimated to be the cause of 99 lakh deaths by 2020 [1]. In children under the age of 19 , at least three lakh new cancer cases have been diagnosed [1]. In therapeutic chemistry, heteroatoms such as $\mathrm{N}$ and $\mathrm{S}$ have gained importance because of their many pharmacological functions [2-22]. 2-Amino-1,3,4-thiadiazoles (I) have been tested as carcinostatic agents against several tissues of implanted animals [3]. The imidazo ring [2,1-b] was fused with 2-amino-1,3,4-thiadiazole, which resulted in imidazo[2,1-b][1,3,4] thiadiazole with antibacterial [4-6], antifungal [7], anti-inflammatory [8,9], anticancer [10], analgesic [11], and antitubercular properties [12,13]. We have reported imidazo[2,1-b][1,3,4]thiadiazoles (II) as cytotoxic agent [14-19]. Recent studies have reported experiments on imidazo[2,1-

\footnotetext{
* Corresponding author.

E-mail address: subhasskarki@gmail.com (S.S. Karki**)
}

b] $[1,3,4]$ thiadiazoles (III) as non-steroidal ecdysone agonists [20]. Our group combined indolinone with imidazothiadiazole in combination and investigated these chemicals as $\mathrm{BCl}_{2}$ inhibitors (IV) [21,22]. Another group tested benzenesulfonamide containing imidazothiadiazole as inhibitors of carbonic anhydrase isoforms [23].

Epidermal growth factor receptor (EGFR) is a protein of transmembrane receptor tyrosine kinase protein expressed in other common epithelial, mesenchymal, and neurogenic tissues. Excessive expression of EGFR was observed in many hard tissues, including lung [24], head-neck [25], ovarian [26], and colon tissue. In addition, EGFR is considered one of the most important targets in the development of new anticancer agents [27]. Therefore, EGFR inhibition was studied using the X-ray crystal form structure (PDB ID: $1 \mathrm{~m} 17$ ) of the molecular docking simulation method. The molecular docking was supported with molecular dynamics simulation study to understand the ligands stability. The purpose of this work is to carry out a cytotoxicity study against human and murine cancer cells and to determine the drug properties of newly synthesized compounds (V) through pharmacokinetic and toxicity analysis in accordance with Lipinski and FAF-Drugs standardsFigure 1 (Fig. 1). 


\section{Experimental}

\subsection{Chemicals and reagents}

Chemicals and reagents used in synthesis were AR grade and procured from local suppliers. The Jasco 430 + was used to record IR sepctra of all the compounds. The Bruker device (400 MHz) was used to record ${ }^{1} \mathrm{H}$ NMR spectra in $\mathrm{CDCl}_{3} / \mathrm{DMSO}_{6} \mathrm{~d}_{6}$ and were reported in hertz (Hz). Various $\alpha$-bromo ketones were prepared as per literature [28-35].

\subsection{Synthetic procedures and spectral data}

\subsubsection{Preparation of 5-(naphthalen-1-ylmethyl)-1,3,4-thiadiazol-2-amine} (3)

Equimolar quantity $(0.3 \mathrm{~mol})$ of naphthyl acetic acid (1) and thiosemicarbazide (2) treated in concentrated sulphuric acid $(31.5 \mathrm{~mL})$ at $60-70^{\circ} \mathrm{C}$ for $8 \mathrm{~h}$. When the reaction conents come to room temperature, poured to cold water \& made basic with concentrated aqueous ammonia to $\mathrm{pH}-7$. Filtered the precipitated mass and washed with $\mathrm{H}_{2} \mathrm{O}$ to remove excess of ammonia. Re-crystallized from chloroform-ethanol mixture. Yield: $70 \%$; m p: $268-270{ }^{\circ} \mathrm{C}$; FT-IR $\left(\mathrm{cm}^{-1}\right)$ : $3273,3078,2964$, 2916, 1634, 1523, 1498, 1523, 1498, 1331, 1060. ${ }^{1} \mathrm{H}$ NMR (400 MHz, DMSO-d $_{6}$ ) $\delta: ~ 8.14-8.12$ (m, 1H, Ar), 8.96-7.94 (m, 1H, Ar), 7.88-7.86 (m, $1 \mathrm{H}, \mathrm{Ar}$ ), 7.56-7.53 (m, 2H, Ar), 7.52-7.48 (m, 2H, Ar), 6.95 (s, br, $2 \mathrm{H}$, $\mathrm{NH}_{2}$ ), 4.61 (s, $2 \mathrm{H},-\mathrm{CH}_{2}$-).

\subsubsection{Preparation of 2-(naphthalen-1-ylmethyl)-6-arylimidazo[2,1-} b] $[1,3,4]$ thiadiazole $(5 a-g)$

The derivatives were obtained by the following general procedure. First, $0.03 \mathrm{~mol}$ of 2-amino-5-(naphthalen-1-ylmethyl)-1,3,4-thiadiazole (3) and appropriate $\alpha$-bromo ketone (4) was condensed for $12 \mathrm{~h}$ in ethyl alcohol. Solvent was removed and the separated solid was filtered, washed with ethyl alcohol, and neutralized to $\mathrm{pH} 7.0$ using aqueous solution of $\mathrm{Na}_{2} \mathrm{CO}_{3}$. The precipitated product was dried and purified from ethyl alcohol.

2.2.2.1. 2-(naphthalen-1-ylmethyl)-6-phenylimidazo[2,1-

b] [1,3,4]thiadiazole (5a). FT-IR $\left(\mathrm{cm}^{-1}\right)$ : 3066, 3037, 2947, 2919, $1607,1525,1474,1441,1258,1061 .{ }^{1} \mathrm{H}$ NMR (400 MHz, DMSO-d 6 ) $\delta: 8.61(\mathrm{~s}, 1 \mathrm{H}, \mathrm{Im}-\mathrm{H}), 8.14(\mathrm{~d}, 1 \mathrm{H}, \mathrm{J}=8 \mathrm{~Hz}), 7.99-7.93(\mathrm{~m}, 2 \mathrm{H}, \mathrm{Ar})$, 7.81-7.79 (m, 2H, Ar), 7.66 (d, $1 \mathrm{H}, \mathrm{J}=6 \mathrm{~Hz}$ ), 7.60-7.52 (m, 3H, Ar), 7.37 (t, 2H, J=15.2 Hz), 7.26 (t, $1 \mathrm{H}, \mathrm{J}=15.0 \mathrm{~Hz}$ ), $4.93\left(\mathrm{~s}, 2 \mathrm{H},-\mathrm{CH}_{2^{-}}\right.$). 2.2.2.2. 6-(4-chlorophenyl)-2-(naphthalen-1-ylmethyl)imidazo[2,1-

b] [1,3,4]thiadiazole (5b) FT-IR $\left(\mathrm{cm}^{-1}\right)$ : 3093, 3027, 2944, 1592, 1531, 1412, 1065, 999. ${ }^{1} \mathrm{H}$ NMR (400 MHz, DMSO-d 6 ) $\delta: 8.67$ (s, $1 \mathrm{H}, \mathrm{Im}-\mathrm{H}$ ), $8.10(\mathrm{~d}, 1 \mathrm{H}, \mathrm{J}=8 \mathrm{~Hz}), 7.99-7.92(\mathrm{~m}, 2 \mathrm{H}, \mathrm{Ar}), 7.83$ (d, $2 \mathrm{H}, \mathrm{J}=8.4 \mathrm{~Hz}$ ), 7.65 (d, $1 \mathrm{H}, \mathrm{J}=6.4 \mathrm{~Hz}$ ), 7.60-7.51 (m, 3H, Ar), 7.45 (d, 2H, J=8.4 Hz), $4.93\left(\mathrm{~s}, 2 \mathrm{H},-\mathrm{CH}_{2^{-}}\right)$.

2.2.2.3. 6-(4-bromophenyl)-2-(naphthalen-1-ylmethyl)imidazo[2,1-

b] $[1,3,4]$ thiadiazole (5c) FT-IR $\left(\mathrm{cm}^{-1}\right): 3120,3065,2931,1585,1522$, 1397, 1071, 1009. ${ }^{1} \mathrm{H}$ NMR (400 MHz, DMSO-d 6 ) $\delta: ~ 8.67$ (s, 1H, Im-H), $8.13(\mathrm{~d}, 1 \mathrm{H}, \mathrm{J}=8 \mathrm{~Hz}), 7.99-7.92(\mathrm{~m}, 2 \mathrm{H}, \mathrm{Ar}), 7.76(\mathrm{~d}, 2 \mathrm{H}, \mathrm{J}=8.2$ $\mathrm{Hz}), 7.65(\mathrm{~d}, 1 \mathrm{H}, \mathrm{J}=7.2 \mathrm{~Hz}), 7.59-7.51(\mathrm{~m}, 5 \mathrm{H}, \mathrm{Ar}), 4.93(\mathrm{~s}, 2 \mathrm{H}$, $-\mathrm{CH}_{2}-$ ).

2.2.2.4. 6-(4-methylphenyl)-2-(naphthalen-1-ylmethyl)imidazo[2,1-

b] [1,3,4]thiadia-zole (5d) FT-IR $\left(\mathrm{cm}^{-1}\right): 3125,3019,2927,2851$, $1621,1545,1481,1476,1302,1192,997 .{ }^{1} \mathrm{H}$ NMR $(400 \mathrm{MHz}$, DMSO-d $_{6}$ ) $\delta: 8.54$ (s, $\left.1 \mathrm{H}, \mathrm{Im}-\mathrm{H}\right), 8.13(\mathrm{~d}, 1 \mathrm{H}, \mathrm{J}=8.0 \mathrm{~Hz}), 7.99-7.92(\mathrm{~m}$, 2H, Ar), 7.70 (d, 2H, J=8.4 Hz), 7.65 (d, 1H, J = 8.0 Hz), 7.89-7.52 (m, $3 \mathrm{H}, \mathrm{Ar}$ ), 7.19 (d, $2 \mathrm{H}, \mathrm{J}=8.0 \mathrm{~Hz}$ ), 4.92 (s, $2 \mathrm{H},-\mathrm{CH}_{2^{-}}$), 2.29 (s, 3H, $\left.-\mathrm{CH}_{3}\right)$.

2.2.2.5. 6-(4-methoxyphenyl)-2-(naphthalen-1-ylmethyl)imidazo[2,1-

b] [1,3,4] thiadiazole (5e) FT-IR $\left(\mathrm{cm}^{-1}\right)$ : 3045, 3008, 2959, 2936, 2834, $1612,1543,1486,1468,1293,1249,1173,1027 .{ }^{1} \mathrm{H}$ NMR $(400 \mathrm{MHz}$, DMSO-d $_{6}$ ) $\delta: 8.49$ (s, $\left.1 \mathrm{H}, \mathrm{Im}-\mathrm{H}\right), 8.12$ (d, $1 \mathrm{H}, \mathrm{J}=8.0 \mathrm{~Hz}$ ), 7.97-7.92 (m, $2 \mathrm{H}, \operatorname{Ar}$ ), 7.73 (d, $2 \mathrm{H}, \mathrm{J}=8.4 \mathrm{~Hz}$ ), 7.63 (d, $1 \mathrm{H}, \mathrm{J}=6.4 \mathrm{~Hz}$ ), 7.59-7.51 (m, 3H, Ar), 6.93 (d, 2H, J=8.4 Hz), $4.91\left(\mathrm{~s}, 2 \mathrm{H},-\mathrm{CH}_{2}-\right), 3.75(\mathrm{~s}, 3 \mathrm{H}$, $\left.-\mathrm{OCH}_{3}\right)$.

2.2.2.6. 2-(naphthalen-1-ylmethyl)-6-(4-nitrophenyl)imidazo[2,1-

b] [1,3,4]thiadiazole (5f) FT-IR $\left(\mathrm{cm}^{-1}\right)$ : 3096, 3060, 3003, 2933, 1599, 1504, 1340, 1181, 1108. ${ }^{1} \mathrm{H}$ NMR (400 MHz, DMSO-d 6 ) $\delta: 8.92(\mathrm{~s}, 1 \mathrm{H}$, Im-H), 8.25 (d, $2 \mathrm{H}, \mathrm{J}=8.4 \mathrm{~Hz}$ ), 8.13 (d, $1 \mathrm{H}, \mathrm{J}=8.0 \mathrm{~Hz}$ ), 8.07 (d, $2 \mathrm{H}$, $\mathrm{J}=8.4 \mathrm{~Hz}$ ), 7.99-7.93 (m, 2H, Ar), 7.66 (d, $1 \mathrm{H}, \mathrm{J}=6.4 \mathrm{~Hz}$ ), 7.59-7.52 (m, 3H, Ar), 4.95 (s, 2H, - $\mathrm{CH}_{2^{-}}$).

2.2.2.7. 3-[2-(naphthalen-1-ylmethyl)imidazo[2,1-b][1,3,4]thiadiazol-6yl]-2H-chromen-2-one (5g) FT-IR $\left(\mathrm{cm}^{-1}\right): 3068,3047,2969,2945$, $1716,1513,1472,1452,1472,1452,1472,1394,1212,1112 .{ }^{1} \mathrm{H}$ NMR

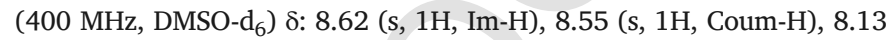
(d, 1H, 8.0 Hz), 7.99-7.94 (m, 2H, Ar), 7.85-7.83 (m, 1H, Ar), 7.67-7.65 (m, 1H, Ar), 7.61-7.52 (m, 4H, Ar), 7.45 (d, 1H, J=8.4 Hz), 7.38 (t, 1H, $\mathrm{J}=16 \mathrm{~Hz}$ ), 4.95 (s, $2 \mathrm{H},-\mathrm{CH}_{2}$ ).

\subsubsection{Preparation of 5-bromo-2-(naphthalen-1-ylmethyl)-6- phenylimidazo[2,1-b] $[1,3,4]$ thiadiazole (6a-e)}

First, $0.01 \mathrm{~mol}$ of bromine was added to a well stirred mixture of powdered anhydrous sodium acetate and $0.01 \mathrm{~mol}$ of 2-(naphthalen-1-ylmethyl)-6-arylimidazo[2,1-b][1,3,4] thiadiazole at room temperature. The agitation was continued for $1 \mathrm{~h}$ and poured into cold water. The solid that formed was filtered, washed with water, and purified. 2.2.3.1. 5-bromo-2-(naphthalen-1-ylmethyl)-6-phenylimidazo[2,1-

b] $[1,3,4]$ thiadiazole (6a) FT-IR $\left(\mathrm{cm}^{-1}\right)$ : 3058, 2962, 2938, 1599, 1528, 1510, 1472, 1440, 1334, 1114, 1071, 966. ${ }^{1} \mathrm{H}$ NMR $(400 \mathrm{MHz}$, DMSO-d ${ }_{6}$ ) $\delta: ~ 8.14$ (d, 1H, J=8.0 Hz), 7.97-7.90 (m, 4H, Ar), 7.67 (d, 1H, $\mathrm{J}=6.4 \mathrm{~Hz}$ ), 7.60-7.52 (m, 3H, Ar), 7.46 (t, 2H, J=15.4 Hz), 7.36-7.32 (m, $1 \mathrm{H}, \mathrm{Ar}), 4.97\left(\mathrm{~s}, 2 \mathrm{H},-\mathrm{CH}_{2}\right.$ ).

2.2.3.2. 5-bromo-6-(4-chlorophenyl)-2-(naphthalen-1-

ylmethyl)imidazo[2,1-b][1,3,4] thiadiazole (6b) FT-IR $\left(\mathrm{cm}^{-1}\right)$ : 3065 , 2932, 2891, 1605, 1535, 1529, 1468, 1368, 1109, 1057. ${ }^{1} \mathrm{H}$ NMR (400 MHz, DMSO-d 6 ) $8: 8.13$ (d, $1 \mathrm{H}, \mathrm{J}=8.0 \mathrm{~Hz}$ ), 8.00-7.92 (m, 4H, Ar), 7.66 (d, $1 \mathrm{H}, \mathrm{J}=7.2 \mathrm{~Hz}$ ), 7.61-7.50 (m, 5H, Ar), 4.98 (s, 2H, - $\mathrm{CH}_{2}$ ). 2.2.3.3. 5-bromo-6-(4-bromophenyl)-2-(naphthalen-1-

ylmethyl)imidazo[2,1-b][1,3,4] thiadiazole (6c) FT-IR $\left(\mathrm{cm}^{-1}\right): 3063$, 3010, 2936, 1903, 1520, 1475, 1395, 1327, 1096, 1006, 967. ${ }^{1} \mathrm{H}$ NMR

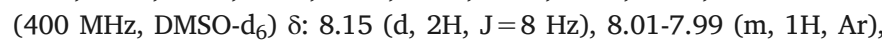
7.97 (d, $1 \mathrm{H}, \mathrm{J}=8.8 \mathrm{~Hz}$ ), 7.89 (d, 2H, J=8.8 Hz), 7.67 (d, 3H, J=8.8 $\mathrm{Hz})$, 7.62-7.53 (m, 3H, Ar), 4.99 (s, $2 \mathrm{H},-\mathrm{CH}_{2}$ ).

2.2.3.4. 5-bromo-6-(4-methylphenyl)-2-(naphthalen-1-

ylmethyl)imidazo[2,1-b][1,3,4] thiadiazole (6d) FT-IR $\left(\mathrm{cm}^{-1}\right)$ : 3076, 3001, 2941, 1515, 1484, 1405, 1321, 1096, 1016. ${ }^{1} \mathrm{H} \mathrm{NMR}(400 \mathrm{MHz}$, DMSO-d $\left.\mathrm{d}_{6}\right)$ : $8.13(\mathrm{~d}, 1 \mathrm{H}, \mathrm{J}=8.4 \mathrm{~Hz}), 7.98-7.94(\mathrm{~m}, 2 \mathrm{H}, \mathrm{Ar}), 7.81(\mathrm{~d}, 2 \mathrm{H}$, $\mathrm{J}=8.0 \mathrm{~Hz}$ ), 7.66-7.52 (m, 4H, Ar), 7.26 (d, 2H, J=8.0 Hz), 4.97 (s, 2H, $\left.-\mathrm{CH}_{2}-\right), 2.32\left(\mathrm{~s}, 3 \mathrm{H},-\mathrm{CH}_{3}\right)$.

2.2.3.5. 5-bromo-6-(4-methoxyphenyl)-2-(naphthalen-1-

ylmethyl)imidazo[2,1-b][1,3,4] thiadiazole (6e) FT-IR $\left(\mathrm{cm}^{-1}\right)$ : 3127, 3045 , 3010, 2960, 2935, 1611, 1543, 1484, 1396, 1300, 1249, 1173, 1027.

2.2.3.6. 5-bromo-2-(naphthalen-1-ylmethyl)-6-(4-nitrophenyl)imidazo[2,1b] $[1,3,4]$ thiadiazole (6f) FT-IR $\left(\mathrm{cm}^{-1}\right): 3107,3025,3005,2959,2829$, 1625, 1491, 1416, 1315, 1198. ${ }^{1} \mathrm{H}$ NMR (400 MHz, DMSO-d 6 ) 8: 8.33 (d, $2 \mathrm{H}, \mathrm{J}=8.8 \mathrm{~Hz}$ ), $8.22(\mathrm{~d}, 2 \mathrm{H}, \mathrm{J}=9.2 \mathrm{~Hz}), 8.15(\mathrm{~d}, 1 \mathrm{H}, \mathrm{J}=8.4 \mathrm{~Hz}$ ), 8.00-7.94 (m, 2H, Ar), 7.67 (d, $1 \mathrm{H}, \mathrm{J}=7.2 \mathrm{~Hz}$ ), 7.62-7.53 (m, 3H, Ar), 5.00 (s, $\left.2 \mathrm{H},-\mathrm{CH}_{2}-\right)$.

2.2.3.7. 3-[5-bromo-2-(naphthalen-1-ylmethyl)imidazo[2,1-

b] [1,3,4] thiadiazol-6-yl]-2H chromen-2-one (6g) FT-IR $\left(\mathrm{cm}^{-1}\right)$ : 3105, 3067, 3005, 2954, 2831, 1629, 1521, 1491, 1399, 1312, 1213, 1198, 1001. ${ }^{1} \mathrm{H}$ NMR (400 MHz, DMSO-d 6 ) $\delta: 8.29$ (s, 1H, Coum-H), 8.14 (d, $1 \mathrm{H}, \mathrm{J}=8.4 \mathrm{~Hz}$ ), 8.00-7.95 (m, 2H, Ar), 7.83-7.80 (m, 1H, Ar), 7.68-7.65 (m, 2H, Ar), 7.63-7.53 (m, 3H, Ar), 7.46 (d, 1H, J=8.4 Hz), 7.38-7.34 (m, $1 \mathrm{H}, \mathrm{Ar}), 4.96$ (s, $2 \mathrm{H},-\mathrm{CH}_{2}$ ). 


\subsubsection{Synthesis of 2-(naphthalen-1-ylmethyl)-6-arylimidazo[2,1-}

b] $[1,3,4]$ thiadiazole-5-carbaldehyde (7a-g)

First, added $4 \mathrm{mmol}$ of 2-(4-methoxybenzyl)-6-aryl-imidazo[2,1-b] $[1,3,4]$ thiadiazole to freshly obtained Vilsmeier-Haack mixture at room temperature with stirring. Continued stirring for $4 \mathrm{~h}$ at $80-90^{\circ} \mathrm{C}$. Later the reaction mixture was poured into cold water and neutralized to $\mathrm{pH} 7.0$ with an aqueous solution of $\mathrm{Na}_{2} \mathrm{CO}_{3}$. The product was filtered and re-crystallized from ethyl alcohol.

2.2.4.1. 2-(naphthalen-1-ylmethyl)-6-phenylimidazo[2,1-

b] [1,3,4] thiadiazole-5-carbaldehyde (7a) FT-IR $\left(\mathrm{cm}^{-1}\right)$ : 3091, 3015, 2929, 2899, 1675, 1563, 1519, 1487, 1455, 1349, 1338, 1091. ${ }^{1} \mathrm{H}$ NMR (400 MHz, DMSO-d $\mathrm{d}_{6}$ ) $\delta: 10.05$ (s, 1H, -CHO), 8.06 (m, 1H, Ar), 7.94-7.90 (m, 2H, Ar), 7.82-7.70 (m, 2H, Ar), 7.58-7.45 (m, 7H, Ar), 4.91 (s, $2 \mathrm{H},-\mathrm{CH}_{2}$ ).

2.2.4.2. 6-(4-chlorophenyl)-2-(naphthalen-1-ylmethyl)imidazo[2,1b] [1,3,4] thiadiazole-5-carbaldehyde (7b) FT-IR $\left(\mathrm{cm}^{-1}\right): 3125,3009$, 2899, 1675, 1599, 1529, 1491, 1355, 1339, 1111. ${ }^{1} \mathrm{H}$ NMR $(400 \mathrm{MHz}$, DMSO-d $\left.{ }_{6}\right) \delta: 10.09$ (s, $\left.1 \mathrm{H},-\mathrm{CHO}\right), 8.03(\mathrm{~d}, 1 \mathrm{H}, \mathrm{J}=8.4 \mathrm{~Hz}), 7.96-7.90(\mathrm{~m}$ $2 \mathrm{H}, \mathrm{Ar}$ ), 7.83 (d, 2H, J=8.4 Hz), 7.58-7.51 (m, 4H, Ar), 7.49 (d, $2 \mathrm{H}$, $\mathrm{J}=8.8 \mathrm{~Hz}), 4.91\left(\mathrm{~s}, 2 \mathrm{H},-\mathrm{CH}_{2}-\right)$.

2.2.4.3. 6-(4-bromophenyl)-2-(naphthalen-1-ylmethyl)imidazo[2,1-

b] [1,3,4] thiadiazole-5-carbaldehyde (7c) FT-IR $\left(\mathrm{cm}^{-1}\right): 3151,3015$, $2915,2892,1681,1598,1515,1478,1450,1350,1325,1091 .{ }^{1} \mathrm{H}$ NMR (400 MHz, DMSO-d ${ }_{6}$ ) : 10.07 (s, $1 \mathrm{H},-\mathrm{CHO}$ ), 8.05 (d, $1 \mathrm{H}, \mathrm{J}=8.4 \mathrm{~Hz}$ ), 7.93 (m, 2H, Ar), 7.75 (d, 2H, J=8.4 Hz), 7.62 (d, 2H, J=8.4 Hz), 7.58-7.49 (m, 4H, Ar), 4.90 (s, $2 \mathrm{H},-\mathrm{CH}_{2}$ ).

2.2.4.4. 6-(4-methylphenyl)-2-(naphthalen-1-ylmethyl)imidazo[2,1-

b] [1,3,4] thiadiazole-5-carbaldehyde (7d) FT-IR $\left(\mathrm{cm}^{-1}\right)$ : 3125, 3025, 2975, 2891, 1665, 1609, 1509, 1465, 1448, 1313, 1121. ${ }^{1} \mathrm{H}$ NMR (400 MHz, DMSO-d ${ }_{6}$ ) 8: 9.94 (s, 1H, -CHO), 8.15 (d, 1H, J=8.4 Hz), 8.00-7.94 (m, 2H, Ar), 7.80 (d, 2H, J=6.8 Hz), 7.61-7.52 (m, 3H, Ar), 7.43 (d, $2 \mathrm{H}, \mathrm{J}=8.4 \mathrm{~Hz}$ ), 5.02 (s, $2 \mathrm{H},-\mathrm{CH}_{2}$ ), 2.35 (s, 3H, $-\mathrm{CH}_{3}$ ). 2.2.4.5. 6-(4-methoxyphenyl)-2-(naphthalen-1-ylmethyl)imidazo[2,1b] [1,3,4] thiadiazole-5-carbaldehyde (7e) FT-IR $\left(\mathrm{cm}^{-1}\right)$ : 3057, 3005, 2936, 2836, 1661, 1607, 1524, 1482, 1395, 1253, 1176, 1110. ${ }^{1} \mathrm{H}$ NMR

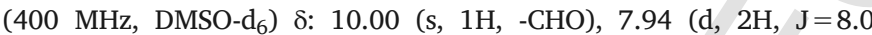
$\mathrm{Hz}$ ), 7.88-7.84 (m, 1H, Ar), 7.75 (d, 2H, J=8.4 Hz), 7.51-7.42 (m, $4 \mathrm{H}, \mathrm{Ar}), 6.97(\mathrm{~d}, 2 \mathrm{H}, \mathrm{J}=8.8 \mathrm{~Hz}), 4.85\left(\mathrm{~s}, 2 \mathrm{H},-\mathrm{CH}_{2}-\right), 3.78(\mathrm{~s}, 3 \mathrm{H}$, $\left.-\mathrm{OCH}_{3}\right)$.

\subsubsection{2-(naphthalen-1-ylmethyl)-6-(4-nitrophenyl)imidazo[2,1}

b] [1,3,4] thiadiazole-5 carbaldehyde (7f) FT-IR $\left(\mathrm{cm}^{-1}\right): 3066,3005$, $2975,2850,1677,1600,1523,1478,1448,1342,1313,1108 .{ }^{1} \mathrm{H}$ NMR (400 MHz, DMSO-d ${ }_{6}$ ) $\delta: 10.07$ (s, $1 \mathrm{H},-\mathrm{CHO}$ ), 8.34 (d, 2H, J =9.2 $\mathrm{Hz}), 8.25$ (d, $2 \mathrm{H}, \mathrm{J}=9.2 \mathrm{~Hz}), 8.15(\mathrm{~d}, 1 \mathrm{H}, \mathrm{J}=8.0 \mathrm{~Hz}), 8.00-7.95(\mathrm{~m}$, $2 \mathrm{H}, \mathrm{Ar}$ ), 7.69 (d, 1H, J=6.4 Hz), 7.61-7.53 (m, 3H, Ar), 5.05 (s, 2H, $-\mathrm{CH}_{2}$ ).

2.2.4.7. 2-(naphthalen-1-ylmethyl)-6-(2-oxo-2H-chromen-3-

yl)imidazo[2,1-b] [1,3,4]thiadiazole-5-carbaldehyde $(7 \mathrm{~g})$ FT-IR $\left(\mathrm{cm}^{-1}\right)$ : 3106, 3009, 2991, 2897, 1683, 1591, 1501, 1467, 1325, 1125. ${ }^{1} \mathrm{H}$ NMR (400 MHz, DMSO-d 6 ) $\delta: 10.01$ (s, 1H, -CHO), 8.49 (s, 1H, Coum-H), 8.13 (d, $1 \mathrm{H}, \mathrm{J}=8.0 \mathrm{~Hz}), 8.01-7.95(\mathrm{~m}, 2 \mathrm{H}, \mathrm{Ar}), 7.87(\mathrm{~d}, 1 \mathrm{H}, \mathrm{J}=8.0 \mathrm{~Hz}$ ), 7.71-7.67 (m, 2H, Ar), 7.62-7.53 (m, 3H, Ar), 7.48 (d, 1H, J=7.6 Hz), 7.38 (t, 1H, J =15.4 Hz), 5.04 (s, 2H, $-\mathrm{CH}_{2}$ )

\subsubsection{Procedure for the preparation of 2-(naphthalen-1-ylmethyl)-6- arylimidazo $[2,1-b][1,3,4]$ thiadiazol-5-yl thiocyanate $(\mathbf{8 a}-\mathbf{g})$}

To a suspension of $8 \mathrm{mmol}$ of potassium thiocyanate and $4 \mathrm{mmol}$ of 2-(4-methoxybenzyl)-6-aryl-imidazo[2,1-b][1,3,4] thiadiazole, $4 \mathrm{mmol}$ of bromine (in $10 \mathrm{~mL}$ of glacial acetic acid) was added under ice at $0-5^{\circ} \mathrm{C}$. The reaction mixture was stirred for $3 \mathrm{~h}$ at room temperature, then poured into ice-cold water and filtered. The product was re-crystallized from ethyl alcohol.

2.2.5.1. 2-(naphthalen-1-ylmethyl)-6-phenylimidazo[2,1-

b] [1,3,4] thiadiazol-5-yl thiocyanate (8a) FT-IR $\left(\mathrm{cm}^{-1}\right)$ : 3091, 3065, 3048, 2935, 2841, 2156, 1598, 1510, 1469, 1340, 1261, $1107 .{ }^{1} \mathrm{H}$ NMR (400 MHz, DMSO-d $\left.{ }_{6}\right)$ $\delta: 8.19(\mathrm{~d}, 1 \mathrm{H}, \mathrm{J}=8.0 \mathrm{~Hz}), 8.00-7.91(\mathrm{~m}$,
4H, Ar), 7.70 (d, $1 \mathrm{H}, \mathrm{J}=6.0 \mathrm{~Hz}$ ), 7.61-7.50 (m, 5H, Ar), 7.46-7.42 (m, $1 \mathrm{H}, \mathrm{Ar}), 5.06$ (s, $2 \mathrm{H},-\mathrm{CH}_{2}$ ).

2.2.5.2. 6-(4-chlorophenyl)-2-(naphthalen-1-ylmethyl)imidazo[2,1-

b] $[1,3,4]$ thiadiazol-5-yl thiocyanate (8b) FT-IR $\left(\mathrm{cm}^{-1}\right)$ : 3101, 3055, 2948, 2839, 2158, 1601, 1508, 1469, 1345, 1262, 1099. ${ }^{1} \mathrm{H}$ NMR (400 MHz, DMSO-d 6 ) $\delta: 8.16$ (d, 1H, J = 8.0 Hz), 8.00-7.92 (m, 4H, Ar), 7.70 (d, $1 \mathrm{H}, 8.0 \mathrm{~Hz}), 7.60-7.53$ (m, 5H, Ar), 5.06 (s, 2H, - $\mathrm{CH}_{2^{-}}$). 2.2.5.3. 6-(4-bromophenyl)-2-(naphthalen-1-ylmethyl)imidazo[2,1 b] [1,3,4] thiadiazol-5-yl thiocyanate (8c) FT-IR $\left(\mathrm{cm}^{-1}\right)$ : 3101, 3005, 2905, 2839, 2166, 1599, 1515, 1475, 1339, 1275, 1111. ${ }^{1} \mathrm{H}$ NMR $(400$ MHz, DMSO-d 6 ) $\delta: 8.07$ (d, 1H, J = 8.0 Hz), 7.95-7.90 (m, 2H, Ar), 7.83 (d, $2 \mathrm{H}, \mathrm{J}=8.4 \mathrm{~Hz}$ ), 7.64-7.49 (m, 6H, Ar), 4.87 (s, 2H, - $\mathrm{CH}_{2}$ ). 2.2.5.4. 6-(4-methylphenyl)-2-(naphthalen-1-ylmethyl)imidazo[2,1-

b] [1,3,4] thiadiazol-5-yl thiocyanate (8d) FT-IR $\left(\mathrm{cm}^{-1}\right)$ : 3046, 3017, 2923, 2868, 2159, 1513, 1469, 1326, 1292, 1264, 1186, 1116. ${ }^{1} \mathrm{H}$ NMR (400 MHz, DMSO-d $\mathrm{d}_{6}$ ) $\delta: 8.04$ (d, $1 \mathrm{H}, \mathrm{J}=8.4 \mathrm{~Hz}$ ), 7.95-7.92 (m, 2H, Ar), 7.83 (d, 2H, J = 8.0 Hz), 7.61-7.50 (m, 4H, Ar), 7.33 (d, 2H, J=8.0 Hz), $4.89\left(\mathrm{~s}, 2 \mathrm{H},-\mathrm{CH}_{2}-\right), 2.17\left(\mathrm{~s}, 3 \mathrm{H},-\mathrm{CH}_{3}\right)$.

2.2.5.5. 6-(4-methoxyphenyl)-2-(naphthalen-1-ylmethyl)imidazo[2,1-

b] [1,3,4] thiadiazol-5-yl thiocyanate (8e) FT-IR $\left(\mathrm{cm}^{-1}\right): 3049,3005$, 2945, 2878, 2161, 1598, 1491, 1475, 1255, $1111 .{ }^{1} \mathrm{H}$ NMR $(400 \mathrm{MHz}$, DMSO- $_{6}$ ) $\delta: ~ 7.97$ (d, $1 \mathrm{H}, \mathrm{J}=8.4 \mathrm{~Hz}$ ), 7.88-7.80 (m, 4H, Ar), 7.53-7.42 (m, 4H, Ar), 6.96 (d, $2 \mathrm{H}, \mathrm{J}=8.8 \mathrm{~Hz}), 4.81$ (s, $2 \mathrm{H},-\mathrm{CH}_{2}$ ), 3.80 (s, $3 \mathrm{H}$, $\left.-\mathrm{OCH}_{3}\right)$.

2.2.5.7. 2-(naphthalen-1-ylmethyl)-6-(4-nitrophenyl)imidazo[2,1-

b] $[1,3,4]$ thiadiazol-5-yl thiocyanate (8f) FT-IR $\left(\mathrm{cm}^{-1}\right)$ : 3091, 3065, 3048, 2935, 2841, 2156, 1598, 1510, 1469, 1340, 1261, 1107. 2.2.5.8. 2-(naphthalen-1-ylmethyl)-6-(2-oxo-2H-chromen-3-

yl)imidazo[2,1-b][1,3,4]thiadiazol-5-yl thiocyanate $(8 \mathrm{~g})$ FT-IR $\left(\mathrm{cm}^{-1}\right)$ : 3071, 3049, 2977, 2928, 2158, 1708, 1606, 1483, 1372, 1163, 1045. ${ }^{1} \mathrm{H}$ NMR (400 MHz, DMSO-d $\left.{ }_{6}\right)$ 8: 8.45 (s, $\left.1 \mathrm{H}, \mathrm{Ar}\right), 8.21-8.19(\mathrm{~m}, 1 \mathrm{H}, \mathrm{Ar})$, 8.01-7.96 (m, 2H, Ar), 7.88-7.86 (m, 1H, Ar), 7.72-7.69 (m, 2H, Ar), 7.59-7.55 (m, 3H, Ar), 7.51 (d, 1H, J=8.4 Hz), 7.42 (t, 1H, J=16 Hz), 5.09 (s, $2 \mathrm{H},-\mathrm{CH}_{2}$ ).

\subsection{Bio-evaluation}

The cytotoxicities of the compounds illustrated in Scheme 1 were studied against human cervix carcinoma HeLa, human T-lymphocyte CEM, and murine leukemia L1210 cell lines [36]. The $\mathrm{IC}_{50}$ values were calculated and expressed in $\mu \mathrm{M}$. All experiments were performed in triplicate.

\subsection{Computational study}

\subsubsection{Details of theoretical calculations}

Optimized structures of all compounds were obtained using the 6-311G(d) basis set [37] and DFT/B3LYP density functional theory [38,39] in Gaussian 09 [40]. AutoDock Vina [41], which includes Lamarckian genetics, was used in PyRx software [42] as the scoring algorithm for molecular docking virtual screening operations. Some molecular descriptors commonly used in absorption, distribution, metabolism, and elimination (ADME) analysis were calculated using the FAF-Drugs4 webserver [43].

\subsubsection{Molecular dynamics simulation studiesScheme 1}

Desmond's Schrodinger tool was used to perform molecular dynamics (MD) simulation studies, which led to the understanding of the binding of ligand-protein complex in the simulated physiological solvent-based system [44,45]. EGFR pdbID: 1M17 truncated to remove $\mathrm{C}$ and $\mathrm{N}$ terminal loops. The fixed structure of the EGFR (residues: 684-951) was used for molecular dynamics. The Molecular Dynamic simulation is performed for 20ns in all chemicals using Desmond under the isothermal-isobaric ensemble at temperatures and pressures set at $300 \mathrm{~K}$ and $1.013 \mathrm{bar}$, respectively. TIP4PEW was used as a solvent model. The boundary is set to $8 \AA$ in the form of a box that is orthorhombic. 


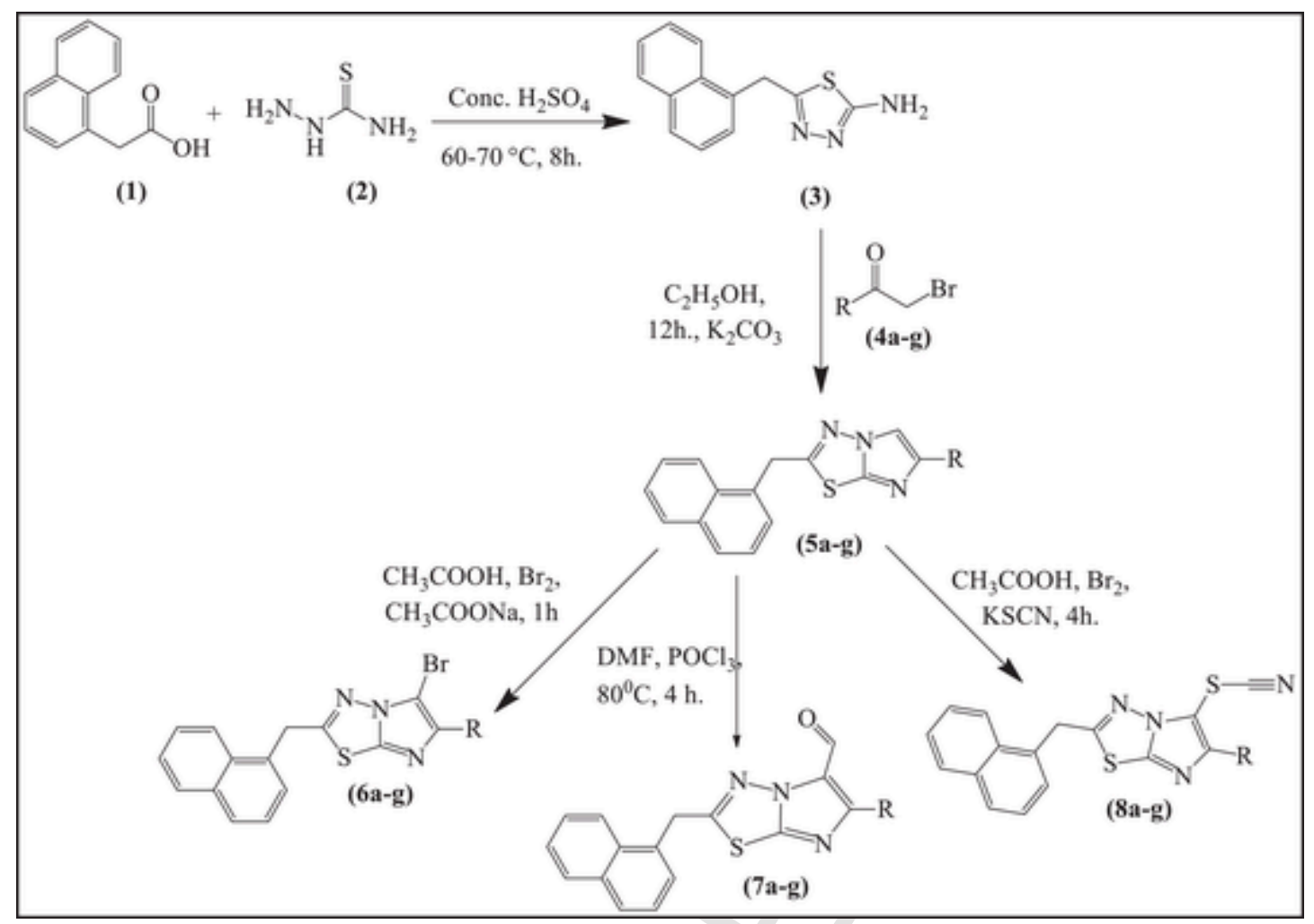

Scheme 1. Synthesis of 2-(naphthalen-1-yl)-methyl-5,6-disubstituted imidazo[2,1-b][1,3,4]thiadiazole.

salt at $0.15 \mathrm{M}$ was added, $\mathrm{Cl}$-counter ions were added to neutralize the system. The recording interval trajectory, every 25 ps and 1000 frames were captured throughout simulation. Root means square deviation (RMSD) calculated by all complex protein combinations. The RMSD shows a moderate change in the location of selected atoms in atoms by comparisons made with the trajectory framework.

\section{Results and discussion}

\subsection{Chemistry}

5-(Naphthalen-1-yl)-methyl-1,3,4-thiadiazole-2-amine (3) was prepared by slowly adding naphthalene-1-acetic acid (1) with stirring to a suspension of thiosemicarbazide (2) in sulfuric acid at $60-70^{\circ} \mathrm{C}$ for $8 \mathrm{~h}$ and cooled to room temperature, added to water, and made basic with an ammonia solution. Different 6-substituted 2-(naphthalen-1-yl)-methylimidazo[2,1-b][1,3,4] thiadiazoles (5a-g) were obtained by reacting 3 with $\alpha$-bromo ketones (4) in ethyl alcohol by heating for $12 \mathrm{~h}$ and neutralizing with aqueous sodium carbonate. The electrophilic substitution reaction was performed at the $5^{\text {th }}$ position of the imidazothiadiazoles (5) to get compounds 6a-g, 7a-g, and 8a-gFigure Scheme 1 (Scheme 1).

Infrared spectroscopy exhibited characteristic C-H stretching vibrations in the range of $3129-3000 \mathrm{~cm}^{-1}$. Aliphatic C-H stretching vibrations were seen between 2999 and $2850 \mathrm{~cm}^{-1}$ and $\mathrm{C}=\mathrm{O}$ stretching vibrations between 1720 and $1640 \mathrm{~cm}^{-1}$ for derivatives $5 \mathrm{~g}, 6 \mathrm{~g}, 7 \mathrm{a}-\mathrm{g}$, and $\mathbf{8 g}$. The derivatives of SCN (8a-g) exhibited stretching vibrations between 2170 and $2150 \mathrm{~cm}^{-1}$.

Protons of the imidazole at $\mathrm{C}_{5}$ were exhibited at 8.92-8.49 ppm for derivatives $5 \mathbf{a}-\mathbf{g}$ in their ${ }^{1} \mathrm{H}$ NMR spectra, which confirms the reaction between aminothiadiazole (3) and the respective 2-bromoketone (4) derivatives. Substitution at the $\mathrm{C}_{5}$ position of imidazothiadiazole was confirmed by the absence of the $\mathrm{C}_{5}-\mathrm{H}$ proton in the respective derivatives (6a-g, 7a-g, and 8a-g).

The presence of a formyl proton was observed for compounds $7 \mathbf{a}-\mathbf{g}$ at 10.09 and $9.94 \delta \mathrm{ppm}$ for their respective proton NMR, which con- firms the Vilsmeier-Haack reaction on the imidazothiadiazole derivatives (5a-g).

All the compounds containing aromatic proton signals exhibited prominent multiplet signals between 8.55 and $6.97 \delta \mathrm{ppm}$. The methylene proton (C2 of imidazothiadiazole) was seen between 5.05 and 4.85 $\delta \mathrm{ppm}$ as a singlet. Methoxy protons of derivatives $\mathbf{5 g}, \mathbf{6 g}, \mathbf{7 g}$, and $8 \mathrm{~g}$ were observed as singlets between 3.80 and $3.75 \delta \mathrm{ppm}$. Methyl protons for derivatives $\mathbf{5 d}, \mathbf{6 d}, \mathbf{7 d}$, and $\mathbf{8 d}$ appeared as singlets between 2.35 and $2.30 \delta \mathrm{ppm}$. Chemical characterization of the synthesized compounds is given in Table 1 .

\subsection{Cytotoxicity study}

Evaluation of the cytotoxic activity of 5-(naphthalen-1-yl)-methyl-6-aryl-imidazo[2,1-b][1,3,4]-thiadiazole derivatives was performed with leukemia murine and human cell lines.

The cytotoxicities of the 27 derivatives of imidazo[2,1-b][1,3,4] thiadiazoles and standards melphalan and levamisole were studied by screening using the CEM, HeLa, and L1210 cells. Among the series of 5a-g against these three cell lines, only $\mathbf{5 g}$ exhibited equipotent activity against $\mathrm{L} 1210[2.1 \mu \mathrm{M}]$ and HeLa cells $[4.0 \mu \mathrm{M}]$ in comparison to standard melphalan $[2.13 \mu \mathrm{M}]$, and it was very much potent in comparison to levamisole [206 $\mu \mathrm{M}$ to $>250 \mu \mathrm{M}$ ]. The remaining derivatives (5a-f) were poor in cytotoxicity for all three cell lines tested. Introduction of bromine at the $5^{\text {th }}$ position of imidazothiadiazole gave 5-bromo derivatives $\mathbf{6 a - g}$ in good yield. Among these 5-bromo derivatives, only $6 \mathrm{~g}$ emerged as the most potent cytotoxic compound against L1210 [3.4 $\mu \mathrm{M}]$ and HeLa cells [4.5 $\mu \mathrm{M}]$. This clearly reveals that $2 \mathrm{H}$-chromen-2-one-3-yl substitution was preferred over the phenyl group at the $6^{\text {th }}$ position of the parent fused heterocyclic ring. The remaining 5-bromo derivatives failed to emerge as cytotoxic compounds against the tested cell lines. Formyl group substitution was introduced at the $5^{\text {th }}$ position by Vilsmeier-Haack reaction on the imidazothiadiazole fused ring to give compounds $\mathbf{7 a - g}$ in good yields. Most of these formyl deriv- 
Table 1

Chemical characterization of the synthesized compounds.

\begin{tabular}{|c|c|c|c|c|c|c|}
\hline & $\mathrm{R}$ & Code & MF & MW & Yield \% & $\mathrm{MP}^{\circ} \mathrm{C}$ \\
\hline & $\mathrm{Ph}$ & $5 a$ & $\mathrm{C}_{21} \mathrm{H}_{15} \mathrm{~N}_{3} \mathrm{~S}$ & 341.43 & 58 & $196-198$ \\
\hline & 4-Cl-Ph & $5 b$ & $\mathrm{C}_{21} \mathrm{H}_{14} \mathrm{ClN}_{3} \mathrm{~S}$ & 375.87 & 61 & $198-200$ \\
\hline & 4-Br-Ph & $5 c$ & $\mathrm{C}_{21} \mathrm{H}_{14} \mathrm{BrN}_{3} \mathrm{~S}$ & 420.32 & 64 & 198-202 \\
\hline & $4-\mathrm{CH}_{3}-\mathrm{Ph}$ & $5 d$ & $\mathrm{C}_{22} \mathrm{H}_{17} \mathrm{~N}_{3} \mathrm{~S}$ & 355.46 & 60 & $180-182$ \\
\hline & $4-\mathrm{OCH}_{3}-\mathrm{Ph}$ & $5 e$ & $\mathrm{C}_{22} \mathrm{H}_{17} \mathrm{~N}_{3} \mathrm{OS}$ & 371.45 & 58 & $194-196$ \\
\hline & $4-\mathrm{NO}_{2}-\mathrm{Ph}$ & $5 f$ & $\mathrm{C}_{21} \mathrm{H}_{14} \mathrm{~N}_{4} \mathrm{O}_{2} \mathrm{~S}$ & 386.43 & 55 & $268-270$ \\
\hline & 2H-chromen-2-one-3-yl & $5 g$ & $\mathrm{C}_{24} \mathrm{H}_{15} \mathrm{~N}_{3} \mathrm{O}_{2} \mathrm{~S}$ & 409.46 & 62 & $220-222$ \\
\hline & $\mathrm{Ph}$ & $6 a$ & $\mathrm{C}_{21} \mathrm{H}_{14} \mathrm{BrN}_{3} \mathrm{~S}$ & 420.32 & 63 & $128-130$ \\
\hline & 4-Cl-Ph & $6 \mathrm{~b}$ & $\mathrm{C}_{21} \mathrm{H}_{13} \mathrm{BrClN}_{3} \mathrm{~S}$ & 454.77 & 67 & $154-156$ \\
\hline & 4-Br-Ph & $6 c$ & $\mathrm{C}_{21} \mathrm{H}_{13} \mathrm{~N}_{3} \mathrm{~S}$ & 499.22 & 62 & $168-170$ \\
\hline & 4- $\mathrm{CH}_{3}-\mathrm{Ph}$ & $6 d$ & $\mathrm{C}_{22} \mathrm{H}_{16} \mathrm{BrN}_{3} \mathrm{~S}$ & 434.35 & 61 & $152-154$ \\
\hline & $4-\mathrm{OCH}_{3}-\mathrm{Ph}$ & $6 e$ & $\mathrm{C}_{22} \mathrm{H}_{16} \mathrm{BrN}_{3} \mathrm{OS}$ & 450.53 & 65 & $138-140$ \\
\hline & $4-\mathrm{NO}_{2}-\mathrm{Ph}$ & $6 f$ & $\mathrm{C}_{21} \mathrm{H}_{13} \mathrm{BrN}_{4} \mathrm{O}_{2} \mathrm{~S}$ & 465.32 & 67 & $184-186$ \\
\hline & 2H-chromen-2-one-3-yl & $6 g$ & $\mathrm{C}_{24} \mathrm{H}_{14} \mathrm{BrN}_{3} \mathrm{O}_{2} \mathrm{~S}$ & 488.36 & 58 & $226-228$ \\
\hline & $\mathrm{Ph}$ & $7 a$ & $\mathrm{C}_{22} \mathrm{H}_{15} \mathrm{~N}_{3} \mathrm{OS}$ & 369.44 & 52 & $154-156$ \\
\hline & 4-Cl-Ph & $7 \mathrm{~b}$ & $\mathrm{C}_{22} \mathrm{H}_{14} \mathrm{ClN}_{3} \mathrm{OS}$ & 403.88 & 51 & $172-174$ \\
\hline & 4-Br-Ph & $7 c$ & $\mathrm{C}_{22} \mathrm{H}_{14} \mathrm{BrN}_{3} \mathrm{OS}$ & 448.34 & 48 & $138-140$ \\
\hline & 4- $\mathrm{CH}_{3}-\mathrm{Ph}$ & $7 d$ & $\mathrm{C}_{23} \mathrm{H}_{17} \mathrm{~N}_{3} \mathrm{OS}$ & 383.47 & 50 & $102-104$ \\
\hline & $4-\mathrm{OCH}_{3}-\mathrm{Ph}$ & $7 e$ & $\mathrm{C}_{23} \mathrm{H}_{17} \mathrm{~N}_{3} \mathrm{O}_{2} \mathrm{~S}$ & 399.46 & 52 & $90-92$ \\
\hline & $4-\mathrm{NO}_{2}-\mathrm{Ph}$ & $7 f$ & $\mathrm{C}_{22} \mathrm{H}_{14} \mathrm{~N}_{4} \mathrm{O}_{3} \mathrm{~S}$ & 414.44 & 53 & $170-172$ \\
\hline & 2H-chromen-2-one-3-yl & $7 \mathrm{~g}$ & $\mathrm{C}_{25} \mathrm{H}_{15} \mathrm{~N}_{3} \mathrm{O}_{3} \mathrm{~S}$ & 437.47 & 48 & $98-101$ \\
\hline $\mathrm{S}=\mathrm{N}$ & $\mathrm{Ph}$ & $8 a$ & $\mathrm{C}_{22} \mathrm{H}_{14} \mathrm{~N}_{4} \mathrm{~S}_{2}$ & 398.50 & 58 & $148-150$ \\
\hline & 4-Cl-Ph & $8 b$ & $\mathrm{C}_{22} \mathrm{H}_{13} \mathrm{ClN}_{4} \mathrm{~S}_{2}$ & 432.95 & 61 & $144-146$ \\
\hline & 4-Br-Ph & $8 \mathrm{c}$ & $\mathrm{C}_{22} \mathrm{H}_{13} \mathrm{BrN}_{4} \mathrm{~S}_{2}$ & 477.40 & 60 & $146-148$ \\
\hline & 4- $\mathrm{CH}_{3}-\mathrm{Ph}$ & $8 d$ & $\mathrm{C}_{23} \mathrm{H}_{16} \mathrm{~N}_{4} \mathrm{~S}_{2}$ & 412.53 & 60 & $102-104$ \\
\hline & $4-\mathrm{OCH}_{3}-\mathrm{Ph}$ & $8 e$ & $\mathrm{C}_{23} \mathrm{H}_{16} \mathrm{~N}_{4} \mathrm{OS}_{2}$ & 428.52 & 61 & $160-162$ \\
\hline & $4-\mathrm{NO}_{2}-\mathrm{Ph}$ & $8 f$ & $\mathrm{C}_{22} \mathrm{H}_{13} \mathrm{~N}_{5} \mathrm{O}_{2} \mathrm{~S}_{2}$ & 443.50 & 60 & $264-266$ \\
\hline & 2H-chromen-2-one-3-yl & $8 g$ & $\mathrm{C}_{25} \mathrm{H}_{14} \mathrm{~N}_{4} \mathrm{O}_{2} \mathrm{~S}_{2}$ & 466.53 & 57 & $258-260$ \\
\hline
\end{tabular}

atives became good cytotoxins against all three cell lines in the range of 4.4-9.7 $\mu \mathrm{M}$ in comparison to the standard drug melphalan [1.4-2.13 $\mu \mathrm{M}]$. Introduction of the thiocyanate $(-\mathrm{SCN})$ group was carried out at the $C_{5}$ position of the imidazothiadiazole fused ring, which resulted in the formation of 5 -thiocyanate compounds 8a-g. Thiocyanate-derivative imidazothiadiazoles were moderately cytotoxic against all three cells, especially against HeLa cells. Compound 8 e (IC (50 $_{5}$ : $9.8 \mu \mathrm{M}$ ) emerged as having the most potent cytotoxic activity against cervix carcinoma cells.

In general, the 5-thiocyanate derivatives exhibited moderate and the 5 -formyl derivatives exhibited good cytotoxicity in comparison to the positive controls, melphalan and levamisole.

Electrophiles such as bromine, formyl, and thiocyanate groups were substituted at the $5^{\text {th }}$ position and aryl groups at the $6^{\text {th }}$ position of the 2-(naphthalen-1-ylmethyl)-imidazothiadiazole fused ring, respectively, to understand the structure-activity relationship (SAR). The presence of the bromine atom did not produce much improvement in cytotoxic activity against all three cell lines tested except for compound $\mathbf{5 g}$ against L1210 leukemia cells $[2.1 \mu \mathrm{M}]$ and against HeLa cervix carcinoma cells $[4.0 \mu \mathrm{M}]$. Compound $\mathbf{5 g}$ emerged as equipotent with the standard drug melphalan. This was due to the presence of $2 H$-1-benzopyran-2-one-3-yl at the $\mathrm{C}_{6}$ position of the imidazothiadiazole-fused ring. Formyl group substitution at $\mathrm{C}_{5}$ of the imidazothiadiazole-fused ring provided good cytotoxins as many of these compounds became potent except $\mathbf{7 d}$ and $\mathbf{7 f}$. The third set of modifications done by thiocyanate substitution at the $\mathrm{C}_{5}$ position of the imidazothiadiazole-fused ring gave compounds with moderate cytotoxicity against all three cell lines tested. Among 
these thiocyanate derivatives, only compound 8e proved to be a good cytotoxin against HeLa cells [9.8 $\mu \mathrm{M}$ ] (Table 2).

\subsection{Molecular docking and calculation of physicochemical and ADME properties}

Table 3 shows the molecular weight (MW), human oral absorption percentage, indicator of hydrophobicity $(\log P)$, topological polar surface area (tPSA), and violation of Lipinski's rule of five (Ro5) [46] calculated for all compounds. The Ro5 was developed by Lipinski et al. as a guide to designing molecules that can be used orally and it has had a notable impact on drug discovery strategies. Four key parameters were selected for $90 \%$ of the molecules studied that could be taken orally:

- A molecular weight (MW) below $500 \mathrm{Da}$

- A calculated octanol-water coefficient (CLogP) smaller than 5

- No more than 5 hydrogen bond donors

- No more than 10 hydrogen bond acceptors

The results in Table 3 indicate that other compounds having experimental activity besides the co-ligand violate the Ro5. Another important value is the tPSA (recommended value: $\leq 140 \AA^{2}$ ) [47], and this value was within the recommended range for all compounds except $\mathbf{8 f}$. On the other hand, $\mathrm{Fsp}^{3}$ (fraction of saturated carbons) is a newer index indicating drug similarity [48]. Lovering et al. [49] pointed out that a decreasing $\mathrm{Fsp}^{3}$ value leads to increased CYP inhibition effect. The $\mathrm{Fsp}^{3}$ values of all compounds were found to be lower than those of the co-ligand, melphalan, and levamisole.

Table 2

Antiproliferative effects of the compounds on L1210, CEM and HeLa cells.

\begin{tabular}{|c|c|c|c|}
\hline Compound & $\mathrm{IC}_{50} *(\mu \mathrm{M})$ & & \\
\hline & L1210 & CEM & HeLa \\
\hline $5 a$ & $116 \pm 6$ & $138 \pm 13$ & $87 \pm 2$ \\
\hline $5 b$ & $94 \pm 49$ & $108 \pm 33$ & $78 \pm 13$ \\
\hline $5 c$ & $>250$ & $111 \pm 20$ & $\geq 250$ \\
\hline $5 d$ & $>250$ & $>250$ & $>250$ \\
\hline $5 e$ & $131 \pm 20$ & $111 \pm 7$ & $120 \pm 36$ \\
\hline $5 f$ & $116 \pm 15$ & $121 \pm 6$ & $117 \pm 52$ \\
\hline $5 g$ & $2.1 \pm 0.8^{* *}$ & $80 \pm 5^{* *}$ & $4.0 \pm 3.1^{* *}$ \\
\hline $6 a$ & $\geq 250$ & $136 \pm 84$ & $>250$ \\
\hline $6 \mathrm{~b}$ & $120 \pm 13$ & $82 \pm 12$ & $79 \pm 14$ \\
\hline $6 c$ & $94 \pm 14$ & $71 \pm 0$ & $66 \pm 18$ \\
\hline $6 \mathrm{~d}$ & $113 \pm 21$ & $77 \pm 2$ & $81 \pm 8$ \\
\hline $6 e$ & $70 \pm 10$ & $51 \pm 5$ & $75 \pm 2$ \\
\hline $6 f$ & $71 \pm 54$ & $64 \pm 17$ & $85 \pm 4$ \\
\hline $6 g$ & $3.4 \pm 1.5$ & $54 \pm 6$ & $4.5 \pm 0.8$ \\
\hline $7 a$ & $9.7 \pm 0.1$ & $7.9 \pm 1.6$ & $8.2 \pm 0.8$ \\
\hline $7 \mathrm{~b}$ & $5.0 \pm 0.5$ & $5.4 \pm 0.3$ & $4.6 \pm 0.4$ \\
\hline $7 c$ & $4.8 \pm 0.3$ & $4.9 \pm 0.4$ & $4.4 \pm 0.5$ \\
\hline $7 d$ & $127 \pm 4$ & $113 \pm 3$ & $86 \pm 14$ \\
\hline $7 e$ & $4.9 \pm 0.5$ & $5.0 \pm 0.0$ & $7.7 \pm 0.2$ \\
\hline $7 f$ & $107 \pm 21$ & $95 \pm 11$ & $74 \pm 12$ \\
\hline $7 g$ & NT & NT & NT \\
\hline $8 \mathrm{a}$ & $57 \pm 39$ & $44 \pm 34$ & $13 \pm 8$ \\
\hline $8 b$ & $66 \pm 0$ & $40 \pm 21$ & $13 \pm 6$ \\
\hline $8 c$ & $79 \pm 31$ & $51 \pm 0$ & $27 \pm 6$ \\
\hline $8 d$ & $82 \pm 11$ & $42 \pm 20$ & $25 \pm 5$ \\
\hline $8 \mathrm{e}$ & $62 \pm 35$ & $53 \pm 1$ & $9.8 \pm 1.9$ \\
\hline $8 f$ & $126 \pm 4$ & $103 \pm 5$ & $70 \pm 5$ \\
\hline $8 g$ & $16 \pm 3$ & $70 \pm 10$ & $28 \pm 22$ \\
\hline Melphalan & $2.13 \pm 0.02$ & $1.4 \pm 0.4$ & NT \\
\hline Levamisole & 206 & $>250$ & $>250$ \\
\hline
\end{tabular}

In addition, Table 3 shows the pharmacological properties of the compounds as well as their binding affinities, and compounds $5 \mathrm{~g}, \mathbf{6 g}$, $7 \mathbf{a}, 7 \mathbf{b}, 7 \mathbf{c}, 7 \mathbf{e}$ and $8 \mathrm{e}$ found to be effective in in vitro studies, and exhbited the highest binding affinity results compared to the co-ligand, melphalan, and levamisole. Similarly, in vitro study showed that the docking score of compound $\mathbf{5 c}$, which had the lowest activity, was also low.

The properties are PhysChem and FAFDrugs filters. HBD: hydrogen bond donor; HBA: hydrogen bond acceptor; tPSA: topological polar surface area; LogP: indicator of hydrophobicity.

In molecular docking studies, the X-ray crystal structure (1m17) of EGFR was used as a target and [6,7-bis(2-methoxy-ethoxy)quinazoline-4-yl]-(3-ethynyl phenyl)amine, the inhibitor of this crystal structure, was used as the co-ligand. The $1 \mathrm{~m} 17$ receptor and all compounds were prepared for docking operations using the protein and ligand preparation wizards in the PyRx package. Docking operations were performed using similar protocols to our previous study [50] for all compounds, the co-ligand molecules, and standards melphalan and levamisole, and the docking scores of all compounds are shown in Table 3. The 3D interactions between the receptor and $\mathbf{5 c}, \mathbf{5 g}, \mathbf{6 g}$, the co-ligand, and standards melphalan and levamisole are shown in Figure 2Fig. 2.

Fig. 3 Figure 3shows the 3D representation of the co-ligand settling in the active binding sites of the target protein and compounds $\mathbf{5 g}$ and $\mathbf{6 g}$, which had high docking scores, and compound $\mathbf{5 c}$, which had a low docking score. Finally, as shown in Fig. 2, all 4 ligands were also observed to be oriented parallel to each other at receptor binding sites.

Molecular Dynamics (MD) simulation studies provide an understanding of the molecular complex of protein-ligand complex interactions and their stability in simulated physiological conditions, employing a Desmond Maestro module. MD simulations were performed on all synthesized compounds. The frame was taken during the 25 ps simulation and kept in trajectory and was followed by the production of 1000 frames in each combination over a simulation time of $25 \mathrm{~ns}$. The 'Ligfit Episode' shows the RMSD (Root Mean Square Deviation) structure of ligand and protein structure. In all compounds, protein-ligand interactions or contacts are observed; in particular the interaction was three types or otherwise four types: hydrogen bonds, hydrophobic intercations, ionic bridges and water (Table 4). Most of the compounds showed strong hydrogen bond interaction with residue MET769, except for the compounds 5d, 5f, 6a-c, $\mathbf{6 e}$ and $\mathbf{8 c}$. In addition to Met769, compounds $\mathbf{8 a}$ and $\mathbf{8 d}$ formed hydrogen bond with residue CYS773, $\mathbf{7 d}$ with residue LYS73 and $\mathbf{8 g}$ with residue THR830. Concerning hydrophobic interactions, residues LEU694, ALA719, and LEU820 were the commonly involved binding with most of the compounds. Besides these there were some ionic and water bridge interactions observed for most of the compounds (Fig.S1). Among the performed molecular dynamics-based simulation studies, the enzyme complex with the compounds $7 \mathbf{b}, 7 \mathbf{c}, 7 \mathrm{e}$, $\mathbf{7 f}, \mathbf{7 g}$, and $\mathbf{8 g}$ showed more stable binding based on RMSD plot shown inFigure 4, 5 and 6 Figs. 4-6 and observed interactions.

\section{Conclusions}

Cytotoxic activities for 28 compounds and two standards were tested against L1210, CEM, and HeLa cells. Among these compounds, 5g, 6g, $7 \mathbf{a}, 7 \mathbf{b}, 7 \mathbf{c}$, and $7 \mathbf{e}$ emerged as the most potent. Overall, formyl substitution was preferred at the $5^{\text {th }}$ position of the imidazo[2,1-b][1,3,4] thiadiazole nucleus as most of the formyl compounds were cytotoxic to all three tested cell lines. The order of potency at the $5^{\text {th }}$ position was $\mathrm{CHO}>\mathrm{SCN}>\mathrm{Br}>\mathrm{H}$. The potency of these compounds was supported by a docking study against the $1 \mathrm{~m} 17$ EGFR receptor. In molecular docking studies, it was observed that all compounds had higher docking scores than [6,7-bis(2-methoxy-ethoxy)quinazoline-4-yl]-(3-ethynylphenyl)amine, an inhibitor of the $1 \mathrm{~m} 17$ receptor. Molecu- 
Table 3

The pharmacological properties of virtual screening and rationally designed compounds.

\begin{tabular}{|c|c|c|c|c|c|c|c|c|c|c|c|c|c|}
\hline Compounds & $\begin{array}{l}\text { Binding } \\
\text { Affinity } \\
\text { (kcal/mol) }\end{array}$ & MW & $\log \mathrm{P}$ & tPSA & $\begin{array}{l}\text { Rotatable } \\
\text { Bonds }\end{array}$ & Flexibility & HBD & HBA & $\begin{array}{l}\text { Lipinski } \\
\text { Violation }\end{array}$ & $\begin{array}{l}\text { Solubility } \\
(\mathrm{mg} / \mathrm{L})\end{array}$ & $\begin{array}{l}\text { Solubility } \\
\text { ForecastIndex }\end{array}$ & $\begin{array}{l}\text { Oral } \\
\text { Bioavailability } \\
\text { VEBER }\end{array}$ & $\mathrm{Fsp}^{3}$ \\
\hline $5 a$ & -9.0 & 341.43 & 5.72 & 58.43 & 3 & 0.1 & 0 & 3 & 1 & 1046.22 & $\begin{array}{l}\text { Reduced } \\
\text { Solubility }\end{array}$ & Good & 0.05 \\
\hline $5 b$ & -8.9 & 375.87 & 6.34 & 58.43 & 3 & 0.1 & 0 & 3 & 1 & 629.48 & $\begin{array}{l}\text { Reduced } \\
\text { Solubility }\end{array}$ & Good & 0.05 \\
\hline $5 c$ & -8.8 & 420.32 & 6.41 & 58.43 & 3 & 0.1 & 0 & 3 & 1 & 511.31 & $\begin{array}{l}\text { Reduced } \\
\text { Solubility }\end{array}$ & Good & 0.05 \\
\hline $5 d$ & -9.1 & 355.46 & 6.08 & 58.43 & 3 & 0.1 & 0 & 3 & 1 & 819.85 & $\begin{array}{l}\text { Reduced } \\
\text { Solubility }\end{array}$ & Good & 0.09 \\
\hline $5 e$ & -8.8 & 371.45 & 5.69 & 67.66 & 4 & 0.13 & 0 & 4 & 1 & 1069.18 & $\begin{array}{l}\text { Reduced } \\
\text { Solubility }\end{array}$ & Good & 0.09 \\
\hline $5 f$ & -9.1 & 386.43 & 5.54 & 104.25 & 4 & 0.13 & 0 & 6 & 1 & 1093.8 & $\begin{array}{l}\text { Reduced } \\
\text { Solubility }\end{array}$ & Good & 0.05 \\
\hline $5 g$ & -10.3 & 409.46 & 5.71 & 88.64 & 3 & 0.09 & 0 & 5 & 1 & 812.93 & $\begin{array}{l}\text { Reduced } \\
\text { Solubility }\end{array}$ & Good & 0.04 \\
\hline $6 a$ & -9.2 & 420.32 & 6.74 & 58.43 & 3 & 0.1 & 0 & 3 & 1 & 415.33 & $\begin{array}{l}\text { Reduced } \\
\text { Solubility }\end{array}$ & Good & 0.05 \\
\hline $6 b$ & -8.9 & 454.77 & 7.37 & 58.43 & 3 & 0.1 & 0 & 3 & 1 & 244.05 & $\begin{array}{l}\text { Reduced } \\
\text { Solubility }\end{array}$ & Good & 0.05 \\
\hline $6 c$ & -8.6 & 499.22 & 7.43 & 58.43 & 3 & 0.1 & 0 & 3 & 1 & 195.83 & $\begin{array}{l}\text { Reduced } \\
\text { Solubility }\end{array}$ & Good & 0.05 \\
\hline $6 d$ & -9.0 & 434.35 & 7.11 & 58.43 & 3 & 0.1 & 0 & 3 & 1 & 321.02 & $\begin{array}{l}\text { Reduced } \\
\text { Solubility }\end{array}$ & Good & 0.09 \\
\hline $6 e$ & -8.8 & 450.35 & 6.71 & 67.66 & 4 & 0.13 & 0 & 4 & 1 & 418 & $\begin{array}{l}\text { Reduced } \\
\text { Solubility }\end{array}$ & Good & 0.09 \\
\hline $6 f$ & -9.1 & 465.32 & 6.57 & 104.25 & 4 & 0.13 & 0 & 6 & 1 & 422.06 & $\begin{array}{l}\text { Reduced } \\
\text { Solubility }\end{array}$ & Good & 0.05 \\
\hline $6 g$ & -10.3 & 488.36 & 6.74 & 88.64 & 3 & 0.09 & 0 & 5 & 1 & 310.69 & $\begin{array}{l}\text { Reduced } \\
\text { Solubility }\end{array}$ & Good & 0.04 \\
\hline $7 a$ & -9.0 & 369.44 & 5.51 & 75.5 & 4 & 0.13 & 0 & 4 & 1 & 1184.03 & $\begin{array}{l}\text { Reduced } \\
\text { Solubility }\end{array}$ & Good & 0.05 \\
\hline $7 \mathrm{~b}$ & -8.9 & 403.88 & 6.14 & 75.5 & 4 & 0.13 & 0 & 4 & 1 & 703 & $\begin{array}{l}\text { Reduced } \\
\text { Solubility }\end{array}$ & Good & 0.05 \\
\hline $7 c$ & -8.7 & 448.34 & 6.2 & 75.5 & 4 & 0.13 & 0 & 4 & 1 & 570.42 & $\begin{array}{l}\text { Reduced } \\
\text { Solubility }\end{array}$ & Good & 0.05 \\
\hline $7 d$ & -9.0 & 383.47 & 5.88 & 75.5 & 4 & 0.13 & 0 & 4 & 1 & 916.81 & $\begin{array}{l}\text { Reduced } \\
\text { Solubility }\end{array}$ & Good & 0.09 \\
\hline $7 e$ & -8.8 & 399.46 & 5.48 & 84.73 & 5 & 0.16 & 0 & 5 & 1 & 1198.47 & $\begin{array}{l}\text { Reduced } \\
\text { Solubility }\end{array}$ & Good & 0.09 \\
\hline $7 f$ & -9.2 & 414.44 & 5.34 & 121.32 & 5 & 0.15 & 0 & 7 & 1 & 1217.01 & $\begin{array}{l}\text { Reduced } \\
\text { Solubility }\end{array}$ & Good & 0.05 \\
\hline $7 \mathrm{~g}$ & - & - & - & - & - & - & - & - & - & - & - & - & - \\
\hline $8 a$ & -9.1 & 398.5 & 6.61 & 107.52 & 4 & 0.13 & 0 & 4 & 1 & 533.37 & $\begin{array}{l}\text { Reduced } \\
\text { Solubility }\end{array}$ & Good & 0.05 \\
\hline $8 b$ & -9.7 & 432.95 & 7.24 & 107.52 & 4 & 0.13 & 0 & 4 & 1 & 314.71 & $\begin{array}{l}\text { Reduced } \\
\text { Solubility }\end{array}$ & Good & 0.05 \\
\hline $8 c$ & -8.7 & 477.4 & 7.3 & 107.52 & 4 & 0.13 & 0 & 4 & 1 & 253.66 & $\begin{array}{l}\text { Reduced } \\
\text { Solubility }\end{array}$ & Good & 0.05 \\
\hline $8 d$ & -9.4 & 412.53 & 6.98 & 107.52 & 4 & 0.13 & 0 & 4 & 1 & 411.89 & $\begin{array}{l}\text { Reduced } \\
\text { Solubility }\end{array}$ & Good & 0.09 \\
\hline $8 \mathrm{e}$ & -9.0 & 428.53 & 6.58 & 116.75 & 5 & 0.16 & 0 & 5 & 1 & 536.91 & $\begin{array}{l}\text { Reduced } \\
\text { Solubility }\end{array}$ & Good & 0.09 \\
\hline $8 f$ & -8.5 & 443.5 & 6.44 & 153.34 & 5 & 0.15 & 0 & 7 & 1 & 543.88 & $\begin{array}{l}\text { Reduced } \\
\text { Solubility }\end{array}$ & Good & 0.05 \\
\hline $8 g$ & -9.7 & 466.53 & 6.61 & 137.73 & 4 & 0.11 & 0 & 6 & 1 & 401.48 & $\begin{array}{l}\text { Reduced } \\
\text { Solubility }\end{array}$ & Good & 0.04 \\
\hline Melphalan & -5.8 & 305.2 & -0.69 & 71.01 & 8 & 0.53 & 3 & 4 & 0 & 125389.7 & $\begin{array}{l}\text { Good } \\
\text { Solubility }\end{array}$ & Good & 0.46 \\
\hline Levamisole & -6.0 & 204.29 & 1.84 & 40.9 & 1 & 0.06 & 0 & 2 & 0 & 19086.31 & $\begin{array}{l}\text { Good } \\
\text { Solubility }\end{array}$ & Good & 0.36 \\
\hline Co-ligand & -7.2 & 393.44 & 3.19 & 74.73 & 10 & 0.36 & 1 & 7 & 0 & 8316.35 & $\begin{array}{l}\text { Reduced } \\
\text { Solubility }\end{array}$ & Good & 0.27 \\
\hline
\end{tabular}

lar dynamics simulation study of the synthesized compounds led to the selection of 6 potent compounds $(7 \mathrm{~b}, \mathbf{7 c}, \mathbf{7 e}, \mathbf{7 f}, \mathbf{7 g}$, and $\mathbf{8 g}$ ) with the good enzyme binding property. These in silico study was supported by in vitro results showed that compounds $\mathbf{7 b}, \mathbf{7 c}$, and $8 \mathrm{~g}$ were most cytotoxic among tested compouds against all three cell lines tested. How- ever further in vivo and other biochemical study required to strengthen these compounds as molecules.

\section{Declarations}

Author contribution statement 


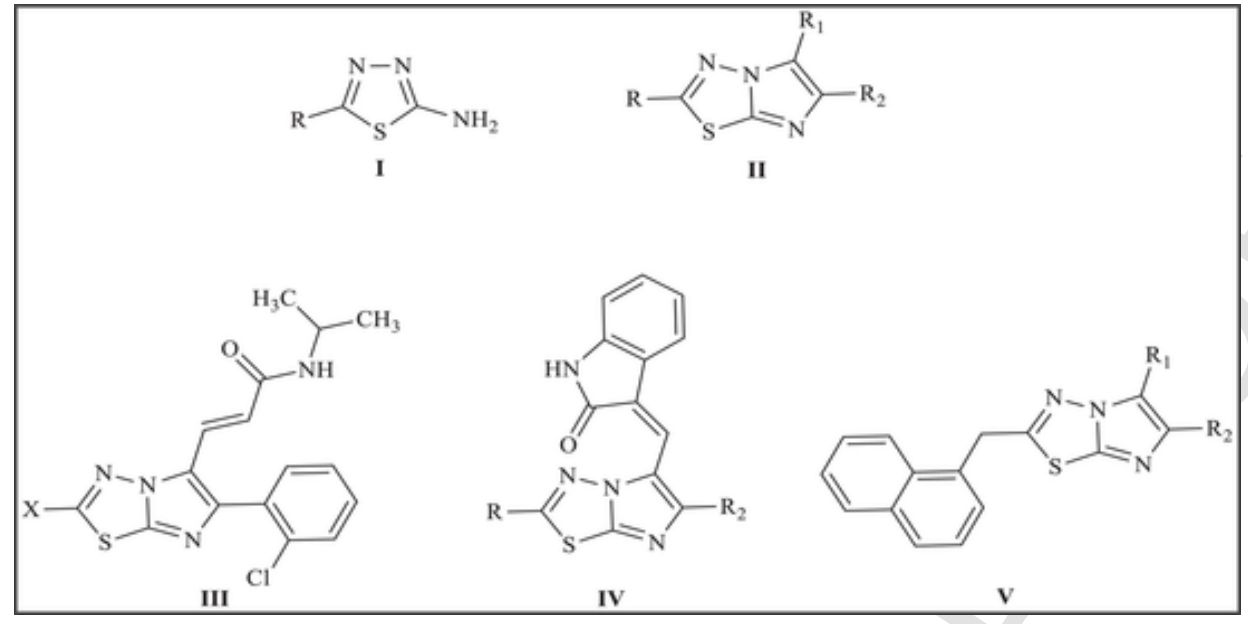

Fig. 1. Structures of aminothiadiazole and imidazothiadiazoles as anticancer and cytotoxic agents.
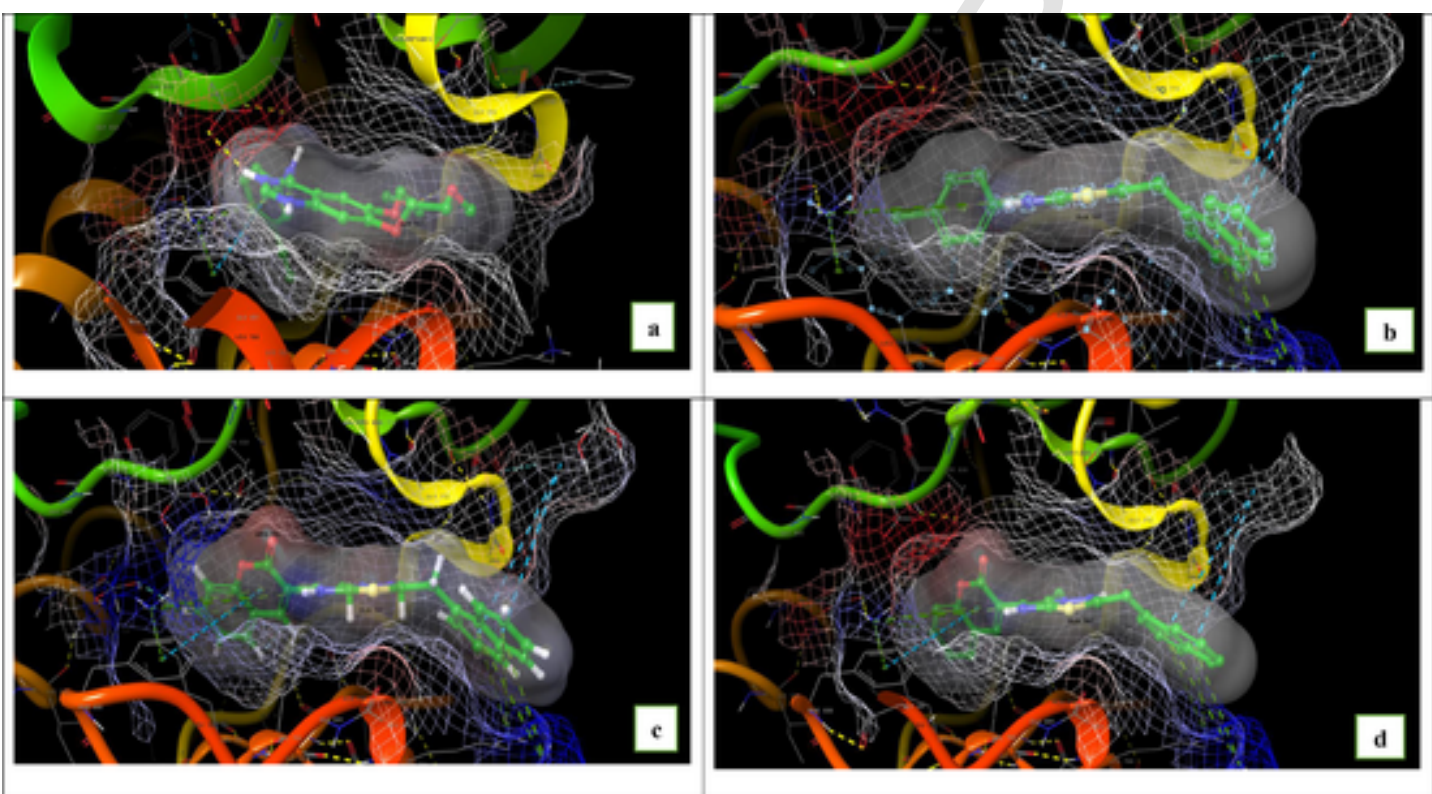

Fig. 2. 3D interactions between the $1 \mathrm{~m} 17$ receptor and compounds a) co-ligand, b) $5 \mathrm{c}, \mathrm{c}$ ) $5 \mathrm{~g}$, and d) $6 \mathrm{~g}$

CB: Performed the synthetic parts of experiment. DS: Carried out cytotoxicity study. HT and TK: Designed and performed the computational study. SK, SB \& RS: performed the molecular dynamics simulation study. SSK: Designed the experiment, analyzed the spectral data, and compiled and wrote the paper.

\section{Credit author statement}

CB: Performed the synthetic parts of experiment.

D S: Carried out cytotoxicity study.

HT and TK: Performed the docking computational study.

SK, SB and RS: Performed the Molecular Dynamics Simulation study

SSK: Designed the experiment, analyzed the spectral data, analyzed the MDS study, compiled, and wrote the paper.

\section{Declaration of Competing Interest}

The authors declare that there is no conflict of interests regarding the publication of the paper.

\section{Acknowledgment}

We would like to thank the NMR Research Centre-Indian Institute of Science, Bengaluru (India) for ${ }^{1} \mathrm{H}$ NMR spectral data.

\section{Supplementary materials}

Supplementary material associated with this article can be found, in the online version, at doi:10.1016/j.molstruc.2021.130174. 


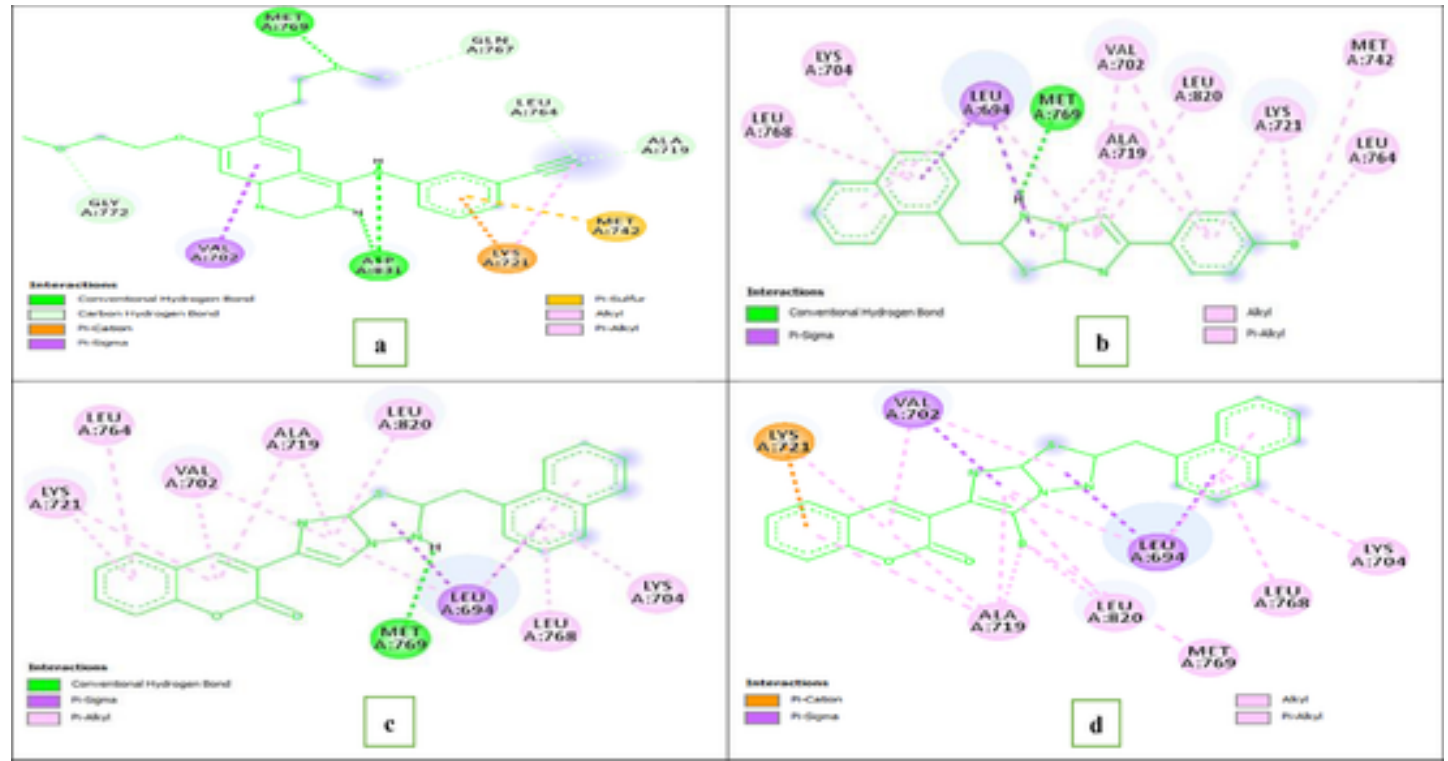

Fig. 3. 2D interactions between $1 \mathrm{~m} 17$ receptor and compounds a) co-ligand b) 5c, c) $5 g$, and d) $6 \mathrm{~g}$. 
Table 4

Prominent molecular interactions towards 1m17 EGFR receptor domain.

\begin{tabular}{|c|c|c|c|}
\hline Compound & Hydrogen bond & $\begin{array}{l}\text { Hydrophobic } \\
\text { Interactions }\end{array}$ & $\begin{array}{l}\text { Others (Ionic, } \\
\text { Water) }\end{array}$ \\
\hline $5 a$ & Met769 & $\begin{array}{l}\text { Leu694, Ala719, } \\
\text { Leu820, Met769 }\end{array}$ & $\begin{array}{l}\text { Leu694, } \\
\text { Cys773 }\end{array}$ \\
\hline $5 b$ & Met769 & $\begin{array}{l}\text { Leu694, Val702, } \\
\text { Ala719, Leu820, } \\
\text { Met769 }\end{array}$ & $\begin{array}{l}\text { Leu694, } \\
\text { Cys773 }\end{array}$ \\
\hline $5 c$ & Met769 & $\begin{array}{l}\text { Leu694, Ala719, } \\
\text { Met742, Leu820 }\end{array}$ & Met769 \\
\hline $5 d$ & - & $\begin{array}{l}\text { Leu694, Ala719, } \\
\text { Met742, Leu820 }\end{array}$ & $\begin{array}{l}\text { Leu694, } \\
\text { Met769 }\end{array}$ \\
\hline $5 e$ & Met769 & $\begin{array}{l}\text { Leu694, Ala719, } \\
\text { Lys721, Met742, } \\
\text { Leu820 }\end{array}$ & $\begin{array}{l}\text { Leu694, } \\
\text { Lys704, } \\
\text { Pro770, } \\
\text { Glu780 }\end{array}$ \\
\hline $5 f$ & - & $\begin{array}{l}\text { Leu694, Phe699, } \\
\text { Val702, Ala719, } \\
\text { Met742, Leu820 }\end{array}$ & $\begin{array}{l}\text { Gln767, } \\
\text { Met769 }\end{array}$ \\
\hline $5 g$ & Met769 & $\begin{array}{l}\text { Leu694, Val702, } \\
\text { Ala719, Leu820 }\end{array}$ & Leu694 \\
\hline $6 a$ & - & $\begin{array}{l}\text { Leu694, Ala719, } \\
\text { Lys721, Leu768, } \\
\text { Leu820 }\end{array}$ & - \\
\hline $6 b$ & - & $\begin{array}{l}\text { Leu694, Val702, } \\
\text { Leu768, Leu820 }\end{array}$ & - \\
\hline $6 c$ & - & $\begin{array}{l}\text { Leu694, Phe699, } \\
\text { Val702, Leu820 }\end{array}$ & $\begin{array}{l}\text { Leu694, } \\
\text { Met769 }\end{array}$ \\
\hline $6 \mathrm{~d}$ & Met769 & $\begin{array}{l}\text { Leu694, Ala719, } \\
\text { Met742, Leu820 }\end{array}$ & $\begin{array}{l}\text { Met769, } \\
\text { Pro770 }\end{array}$ \\
\hline $6 e$ & - & $\begin{array}{l}\text { Leu694, Val702, } \\
\text { Leu768 }\end{array}$ & $\begin{array}{l}\text { Lys721, } \\
\text { Glu738, } \\
\text { Asp831 }\end{array}$ \\
\hline $6 f$ & $\begin{array}{l}\text { Lys721 } \\
\text { Leu694, Phe699, } \\
\text { Val702, Leu820, } \\
\text { Lys721 }\end{array}$ & $\begin{array}{l}\text { Lys721, Thr766, } \\
\text { Gln767, Met769, } \\
\text { Asp831 }\end{array}$ & \\
\hline $6 g$ & $\begin{array}{l}\text { Met769 } \\
\text { Leu694, Val702, } \\
\text { Ala719, Phe771, } \\
\text { His781, Leu820 }\end{array}$ & Leu694 & \\
\hline $7 a$ & Met769 & $\begin{array}{l}\text { Leu694, Val702, } \\
\text { Ala719, Leu820 }\end{array}$ & - \\
\hline $7 \mathrm{~b}$ & Met769 & $\begin{array}{l}\text { Leu694, Val702, } \\
\text { Ala719, Lys721, } \\
\text { Leu820 }\end{array}$ & $\begin{array}{l}\text { Lys721, } \\
\text { Met769 }\end{array}$ \\
\hline $7 c$ & $\begin{array}{l}\text { Met769 } \\
\text { Leu694, Val702, } \\
\text { Ala719, Leu764, } \\
\text { Leu768, Leu820 }\end{array}$ & - & \\
\hline $7 d$ & Met769, Lsy721 & $\begin{array}{l}\text { Leu694, Val702, } \\
\text { Ala719, Leu820 }\end{array}$ & $\begin{array}{l}\text { Lys721, } \\
\text { Met769, }\end{array}$ \\
\hline $7 \mathrm{e}$ & Met769 & $\begin{array}{l}\text { Leu694, Ala719, } \\
\text { Lys721, Met742, } \\
\text { Leu820 }\end{array}$ & $\begin{array}{l}\text { Lys704, } \\
\text { Met769, } \\
\text { Pro770 }\end{array}$ \\
\hline $7 f$ & Met769 & $\begin{array}{l}\text { Val702, Ala719, } \\
\text { Met769, Leu820 }\end{array}$ & Leu694 \\
\hline $7 \mathrm{~g}$ & Thr830 & $\begin{array}{l}\text { Leu694, Ala719, } \\
\text { Lys721, Met742, } \\
\text { Leu768 }\end{array}$ & $\begin{array}{l}\text { Lys721, } \\
\text { Thr830, } \\
\text { Asp831 }\end{array}$ \\
\hline $8 a$ & Met769, Cys773 & $\begin{array}{l}\text { Leu694, Phe699, } \\
\text { Leu } 820\end{array}$ & $\begin{array}{l}\text { Cys773, } \\
\text { Asp776 }\end{array}$ \\
\hline $8 b$ & Met769 & $\begin{array}{l}\text { Leu694, Ala719, } \\
\text { Lys721, Met742, } \\
\text { Leu820 }\end{array}$ & $\begin{array}{l}\text { Cys773, } \\
\text { Asp776 }\end{array}$ \\
\hline $8 c$ & - & $\begin{array}{l}\text { Leu694, Lys721, } \\
\text { Leu768 }\end{array}$ & $\begin{array}{l}\text { Ser696, } \\
\text { Met769 }\end{array}$ \\
\hline $8 d$ & Met769, Cys773 & $\begin{array}{l}\text { Leu694, Ala719, } \\
\text { Lys721, Met742, } \\
\text { Leu820 }\end{array}$ & $\begin{array}{l}\text { Pro770, } \\
\text { Cys773, } \\
\text { Asp776 }\end{array}$ \\
\hline
\end{tabular}

\begin{tabular}{llll}
\hline \multirow{2}{*}{ Compound } & Hydrogen bond & $\begin{array}{l}\text { Hydrophobic } \\
\text { Interactions }\end{array}$ & $\begin{array}{l}\text { Others (Ionic, } \\
\text { Water) }\end{array}$ \\
\hline 8e & Met769 & $\begin{array}{l}\text { Leu694, Ala719, } \\
\text { Lys721, Met742 }\end{array}$ & $\begin{array}{l}\text { Met769, } \\
\text { Lys704, } \\
\end{array}$ \\
& & & $\begin{array}{l}\text { Pro770, } \\
\text { Asp776 }\end{array}$ \\
& \multirow{2}{*}{ Met769 } & Leu694, Phe699, & Leu694, \\
& \multirow{2}{*}{ Met769, Thr830 } & Leu820 & Met769, sp776 \\
& & Val702, Ala719, & Arg817, \\
& & Leu768, Leu820 & Thr830, \\
& & & Asp831 \\
\hline
\end{tabular}



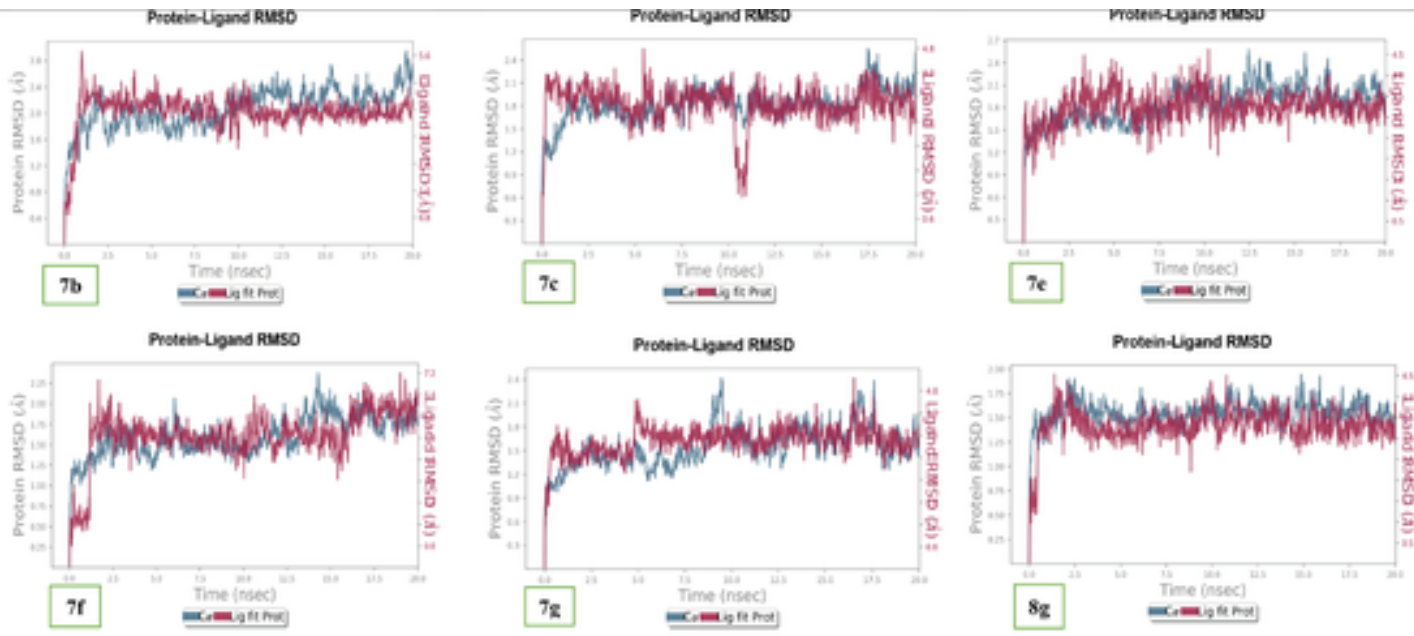

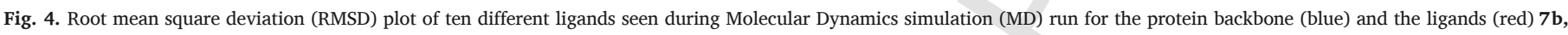
$7 \mathrm{c}, 7 \mathrm{e}, 7 \mathrm{f}, 7 \mathrm{~g}$, and $8 \mathrm{~g}$.
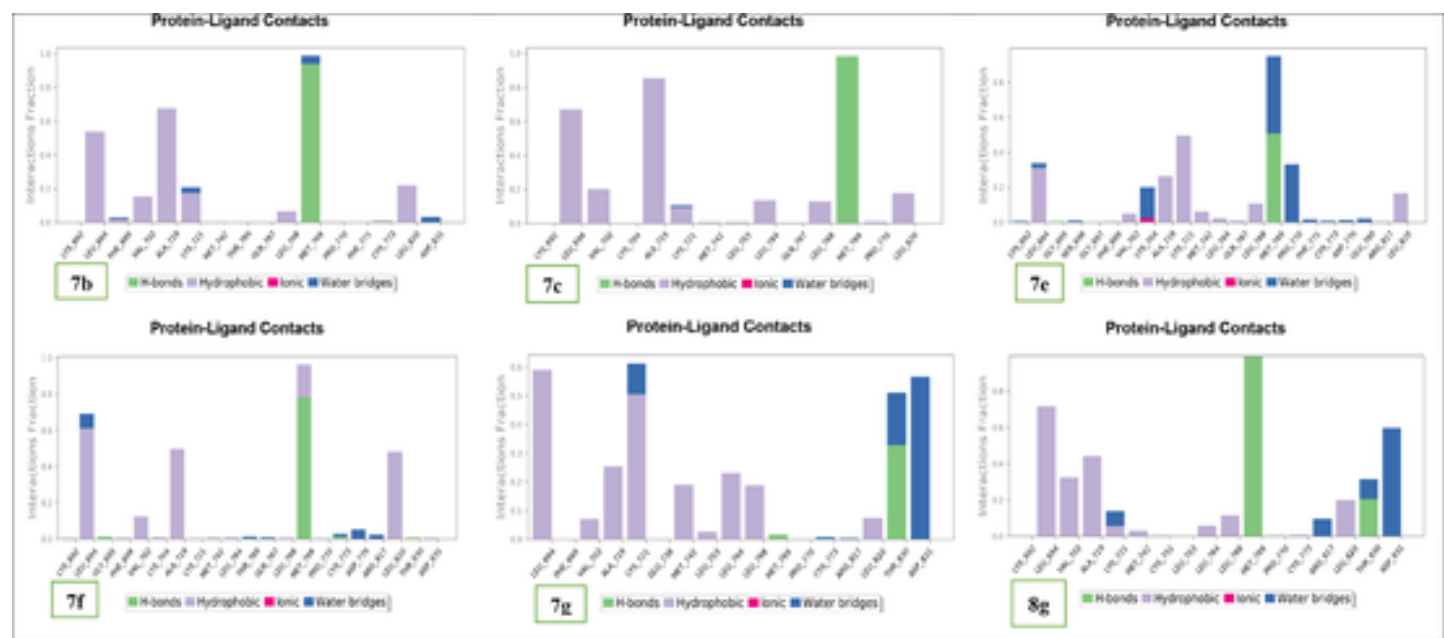

Fig. 5. Protein ligand contact for the compounds $7 \mathrm{~b}, \mathbf{7 c}, \mathbf{7 e}, \mathbf{7 f}, \mathbf{7 g}$, and $\mathbf{8 g}$.
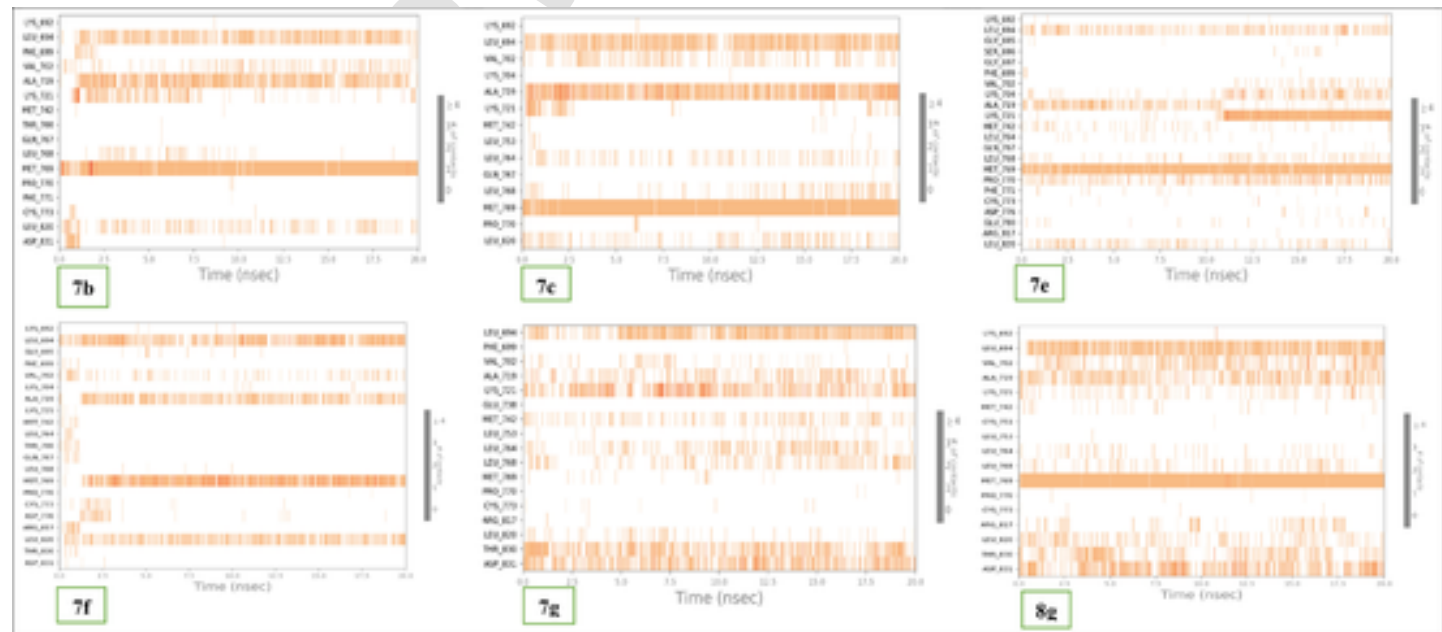

Fig. 6. Protein ligand timeline for the compounds $7 \mathrm{~b}, 7 \mathrm{c}, 7 \mathrm{e}, 7 \mathrm{f}, \mathbf{7 g}$, and $8 \mathrm{~g}$ 


\section{References}

[1] Cancer facts and statistics: WHO (n.d) retrieved from www.who.int/healthtopics/cancer\#tab = tab_1. 2020.

[2] M.L. Fascio, M. InésErrea, N. BeatrizD'Accorso, Imidazothiazole and related heterocyclic systems. Synthesis, chemical and biological properties, Eur. J. Med. Chem. 90 (2015) 666-683, doi:10.1016/j.ejmech.2014.12.012.

[3] J.J. Oleson, A. Sloboda, W.P. Troy, S.L. Halliday, M.J. Landes, R.B. Angier, J. Semb, K. Cyr, J.H. Williams, The carcinostatic activity of some 2-amino-1,3,4-thiadiazoles, J. Am. Chem. Soc. 77 (1955) 6713-6714, doi:10.1021/ja01629a133.

[4] M.A. El-Hashash, S.A. Rizk, S.A. Atta-Allah, Synthesis and regioselective reaction of some unsymmetrical heterocyclic chalcone derivatives and spiro heterocyclic compounds as antibacterial agents, Molecules 20 (2015) 22069-22083, doi:10.3390/molecules201219827.

[5] S. Dhepe, S. Kumar, R. Vinayakumar, S.A. Ramareddy, S.S. Karki, Microwave-assisted synthesis and antimicrobial activity of some imidazo[2,1-b][1,3,4] thiadiazole derivatives, Med. Chem. Res. 21 (2012) 1550-1556, doi:10.1007/s00044-011-9671-8.

[6] A.K. Gadad, C.S. Mahajanshetti, S. Nimbalkar, A. Raichurkar, Synthesis and antibacterial activity of some 5-guanylhydrazone/ thiocyanato-6-arylimidazo[2,1-b]-1,3,4-thiadiazole-2-sulfonamide derivatives, Eur. J. Med. Chem. 35 (2000) 853-857, doi:10.1016/s0223-5234(00)00166-5

[7] W.S. Alwan, R. Karpoormath, M.B. Palkar, H.M. Patel, R.A. Rane, M.S. Shaikh, A. Kajee, K.P. Mlisana, Novel imidazo[2,1-b]-1,3,4-thiadiazoles as promising antifungal agents against clinical isolate of Cryptococcus neoformans, Eur. J. Med. Chem. 95 (2015) 514-525, doi:10.1016/j.ejmech.2015.03.021.

[8] V.B. Jadhav, M.V. Kulkarni, V.P. Rasal, S.S. Biradar, M.D. Vinay, Synthesis and antiinflammatory evaluation of methylene bridged benzofuranyl imidazo[2,1-b][1,3,4] thiadiazoles, Eur. J. Med. Chem. 43 (2008) 1721-1729, doi:10.1016/j.ejmech.2007.06.023.

[9] A.K. Gadad, M.B. Palkar, K. Anand, M.N. Noolvi, T.S. Boreddy, J. Wagwade, Synthesis and biological evaluation of 2-trifluoromethyl/sulfonamido-5,6-diaryl substituted imidazo[2,1-b]-1,3,4-thiadiazoles: a novel class of cyclooxygenase-2 inhibitors, Bioorg. Med. Chem. 16 (2008) 276-283, doi:10.1016/ j.bmc.2007.09.038.

[10] M.N. Noolvi, H.M. Patel, S. Kamboj, A. Kaur, V. Mann, 2,6-Disubstituted imidazo[2,1-b][1,3,4]thiadiazoles: search for anticancer agents, Eur. J. Med. Chem. 56 (2012) 56-69, doi:10.1016/j.ejmech.2012.08.012.

[11] I.A. Khazi, M C.S. Mahajanshetti, A.K. Gadad, A.D. Tarnalli, C.M. Sultanpure, Synthesis, anticonvulsant and analgesic activities of some 6-substituted imidazo-(2,1-b)-1,3,4-thiadiazole-2-sulfonamides and their 5-bromo derivatives, Arzneimittelforschung 46 (1996) 949-952.

[12] S.G. Alegaon, K.R. Alagwadi, P.V. Sonkusara, S.M. Chaudhary, D.H. Dadwe, A.S. Shah, Novel imidazo[2,1-b][1,3,4] thiadiazole carrying rhodanine-3-acetic acid as potential antitubercular agents, Bioorg. Med. Chem. Lett. 22 (2012) 1917-1921, doi:10.1016/j.bmcl.2012.01.052.

[13] A.K. Gadad, M.N. Noolvi, R.V. Karpoormath, Synthesis and anti-tubercular activity of a series of 2-sulfonamido/trifluoromethyl-6-substituted imidazo[2,1-b]-1,3,4-thiadiazole derivatives, Bioorg. Med. Chem. 12 (2004) 5651-5659, doi:10.1016/j.bmc.2004.07.060.

[14] S. Kumar, V. Gopalakrishnan, M. Hegde, V. Rana, S.S. Dhepe, S.A. Ramareddy, A. Leoni, A. Locatelli, R. Morigi, M. Rambaldi, M. Srivastava, S.C. Raghavan, S.S. Karki, Synthesis and antiproliferative activity of imidazo[2,1-b] $[1,3,4]$ thiadiazole derivatives, Bioorg. Med. Chem. Lett. 24 (2014) 4682-4688, doi:10.1016/j.bmcl.2014.08.032.

[15] S. Kumar, M. Hegde, V. Gopalakrishnan, R. Vinayakumar, S.A. Ramareddy, E. De Clercq, D. Schols, G.N. Anilkumar, S.C. Raghavan, S.S. Karki, 2-(4-Chlorobenzyl)-6-arylimidazo[2,1-b][1,3,4]thiadiazoles: synthesis, cytotoxic activity and mechanism of action, Eur. J. Med. Chem. 84 (2014) 687-697, doi:10.1016/j.ejmech.2014.07.054.

[16] S.S. Karki, K. Panjamurthy, S. Kumar, M. Nambiar, S.A. Ramareddy, K.K. Chiruvella, S.C. Raghavan, Synthesis and biological evaluation of novel 2-aralkyl-5-substituted-6-(4'-fluorophenyl)-imidazo[2,1-b][1,3,4]thiadiazole derivatives as potent anticancer agents, Eur. J. Med. Chem. 46 (2011) 2109-2116, doi:10.1016/j.ejmech.2011.02.064.

[17] A.K. Gadad, S.S. Karki, V.G. Rajurkar, B.A. Bhongade, Synthesis and biological evaluation of

5-formyl-6-arylimidazo(2,1-b)-1,3,4-thiadiazole-2-N-(dimethylaminomethi no) sulfonamides as antitumor agents, Arzneimittelforschung 49 (1999) 858-863, doi:10.1055/s-0031-1300515.

[18] M. Hegde, S.S. Karki, E. Thomas, S. Kumar, K. Panjamurthy, S.R. Ranganatha, K.S. Rangappa, B. Choudhary, S.C. Raghavan, Novel levamisole derivative induces extrinsic pathway of apoptosis in cancer cells and inhibits tumor progression in mice, PLoS One 7 (2012) e43632, doi:10.1371/ journal.pone.0043632

[19] B. Choodamani, K.G.C. Hernandez, S. Kumar, A.M. Tony, A.Y.S. Bustamante, R.J. Aguilera, D. Schols, C.G. Mohan, Synthesis, molecular docking and preliminary antileukemic activity of 4-methoxybenzyl derivatives bearing an imidazo[2,1-b][1,3,4]thiadiazoles, Chem. Biodiversity (2020) Dec 4, doi:10.1002/cbdv.202000800.

[20] T. Yokoi, Y. Nakagawa, H. Miyagawa, Quantitative structure-activity relationship of substituted imidazothiadiazoles for their binding against the ecdysone receptor of Sf-9 cells, Bioorg. Med. Chem. Lett. 27 (2017) 5305-5309, doi:10.1016/j.bmcl.2017.10.013.

[21] S.V. Vartak, M. Hegde, D. Iyer D, S. Gaikwad, V. Gopalakrishnan, M. Srivastava, S.S. Karki, B. Choudhary, P. Ray, T.R. Santhoshkumar, S.C. Raghavan, A novel inhibitor of BCL2, Disarib abrogates tumor growth while sparing platelets, by activating intrinsic pathway of apoptosis, Biochem. Pharmacol. 122 (2016) 10-22, doi:10.1016/j.bcp.2016.09.028.
[22] D. Iyer, S.V. Vartak, A. Mishra, G. Goldsmith, S. Kumar, M. Srivastava, M Hegde, V. Gopalakrishnan, M. Glenn, M. Velusamy, B. Choudhary, N. Kalakonda, S.S. Karki, A. Surolia, S.C. Raghavan, Identification of a novel BCL2-specific inhibitor that binds predominantly to the BH1 domain, The FEBS J. 283 (2016) 3408-3437, doi:10.1111/febs.13815.

[23] R. Kumar, S. Bua, S. Ram, S.D. Prete, C. Capasso, C.T. Supuran, P.K. Sharma, Benzenesulfonamide bearing imidazothiadiazole and thiazolotriazole scaffold as potent tumor associated human carbonic anhydrase IX and XII inhibitors, Bioorg. Med. Chem. 25 (2017) 1286-1293, doi:10.1016/j.bmc.2016.12.047.

[24] T. Mitsudomi, Y. Yatabe, Epidermal growth factor receptor in relation to tumor development: EGFR gene and cancer, The FEBS J. 277 (2010) 301-308, doi:10.1111/j.1742-4658.2009.07448.x

[25] S. Kalyankrishna, J.R. Grandis, Epidermal growth factor receptor biology in head and neck cancer, J. Clin. Onc. 24 (2006) 2666-2672, doi:10.1200/ JCO.2005.04.8306.

[26] J. Morrison, K. Haldar, S. Kehoe, T.A. Lawrie, Chemotherapy versus surgery for initial treatment in advanced ovarian epithelial cancer, Cochrane Database Syst. Rev. 15 (8) (2012), doi:10.1002/14651858.CD005343.pub3.

[27] P. Jain, V. Singh, S. Ali, V. Tripathi, U. Saraswat, Synthesis, characterization, molecular docking and biological activity of 5, 6-bis-(4-fluoro-phenyl)-3, 4, 7, 8-tetraaza-bicyclo [8.3. 1] tetradeca-1 (13), 4, 6, 10 (14), 11-pentaene-2, 9-dione and its transition metal complexes, J. Saudi Chem. Soc. 22 (2018) 546-557.

[28] A.H. Blatt, Organic Synthesis Coll, vol. 2, John Wiley \& Sons, pp. 480.

[29] J. Hartung, M. Schwarz, Towards improved alkoxyl radical precursors - the synthesis of N-alkoxy-4-(p-chlorophenyl)thiazole-2(3H)-thiones, Synlett 7 (1997) 848-850, doi:10.1055/s-1997-5754.

[30] T. Ganesh, Ch Harish Kumar, G.L. David Krupadanam, A facile synthesis of 2-hydroxy-2-aryl-1,4-benzodioxanes, Synth. Commun. 29 (1999) 2069-2078, doi:10.1080/00397919908086199.

[31] D.L.J. Clive, S. Hisaindee, D.M. Coltart, Derivatized amino acids relevant to native peptide synthesis by chemical ligation and acyl transfer, J. Org. Chem. 68 (2003) 9247-9254, doi:10.1021/jo030192r.

[32] M. Ogata, H. Matsumoto, S. Kida, S. Shimizu, K. Tawara, Y. Kawamura, Synthesis and antifungal activity of a series of novel 1,2-disubstituted propenones, J. Med. Chem. 30 (1987) 1497-1502, doi:10.1021/jm00391a037.

[33] S.A. Laufer, D.R.J. Hauser, A.J. Liedtke, Regiospecific and highly flexible synthesis of 1,4,5-trisubstituted 2-sulfanylimidazoles from structurally diverse ethanone precursors, Synthesis 2 (2008) 253-266, doi:10.1055/ s-2007-1000852.

[34] P. Wan, X. Xu, Disproportionation of 4-nitroacetophenone to 4-aminoacetophenone and 4-nitrobenzoic acid, J. Org. Chem. 54 (1989) 4473-4474, doi:10.1021/jo00279a045.

[35] C.F. Koelsch, Bromination of 3-acetocoumarin, J. Am. Chem. Soc. 72 (1950) 2993-2995, doi:10.1021/ja01163a053.

[36] P.B. Baraldi, M. del C. Nunez, M.A. Tabrizi, E.De Clercq, J. Balzarini, J Bermejo, F. Estévez, R. Romagnoli, Design, synthesis, and biological evaluation of hybrid molecules containing $\alpha$-methylene- $\gamma$-butyrolactones and polypyrrole minor groove binders, J. Med. Chem. 47 (2004) 2877-2886, doi:10.1021/ jm031104y.

[37] J.B. Foresman, A. Frisch, A. Exploring chemistry with electronic structure methods: a guide to using Gaussian, 1996

[38] A.D. Becke, Density-functional thermochemistry. III. The role of exact exchange, The J. Chem. Phys. 98 (1993) 5648-5652, doi:10.1063/1.464913.

[39] C. Lee, W. Yang, R.G. Parr, Development of the Colle-Salvetti correlation-energy formula into a functional of the electron density, Phys. Rev. B 37 (785) (1988), doi:10.1103/PhysRevB.37.785.

[40] M. Frisch, G. Trucks, H.B. Schlegel, G. Scuseria, M. Robb, J. Cheeseman, G. Scalmani, V. Barone, B. Mennucci, G. Petersson, Gaussian 09, revision a. 02, gaussian. Inc., Wallingford, CT, 2009, p. 200.

[41] O. Trott, A.J. Olson, AutoDock Vina: improving the speed and accuracy of docking with a new scoring function, efficient optimization, and multithreading, J. Comput. Chem. 31 (2010) 455-461, doi:10.1002/jcc.21334.

[42] S. Dallakyan, PyRx-python prescription v. 0.8, 2010, The Scripps Research Institute, 2008

[43] D. Lagorce, O. Sperandio, H. Galons, M.A. Miteva, B.O. Villoutreix, FAF-Drugs2: free ADME/tox filtering tool to assist drug discovery and chemical biology projects, BMC Bioin 9 (396) (2008), doi:10.1186/1471-2105-9-396.

[44] E. Chow, C.A. Rendleman, K.J. Bowers, R.O. Dror, J. Gullingsrud, F.D. Sacerdoti, D.E. Shaw, Desmond performance on a cluster of multicore processors, (n.d.) 14. [20]Desmond | Schrödinger, (n.d.). https://www.schrodinger.com/ desmond (accessed 10 December 2020).

[45] Desmond Schrödinger, (n.d.). https://www.schrodinger.com/desmond (accessed on 10 December, 2020)

[46] C.A. Lipinski, F. Lombardo, B.W. Dominy, P.J. Feeney, Experimental and computational approaches to estimate solubility and permeability in drug discovery and development settings, Adv. Drug Del. Rev. 23 (1997) 3-25, doi:10.1016/S0169-409X(96)00423-1.

[47] D.F. Veber, S.R. Johnson, H.-Y. Cheng, B.R. Smith, K.W. Ward, K.D. Kopple, Molecular properties that influence the oral bioavailability of drug candidates, J. Med. Chem. 45 (2002) 2615-2623, doi:10.1021/jm020017n.

[48] K. Hirata, M. Kotoku, N. Seki, T. Maeba, K. Maeda, S. Hirashima, T. Sakai, S. Obika, A. Hori, Y. Hase, SAR exploration guided by LE and Fsp3: discovery of a selective and orally efficacious ROR $\gamma$ inhibitor, ACS Med. Chem. Lett. 7 (2016) 23-27, doi:10.1021/acsmedchemlett.5b00253.

[49] F. Lovering, J. Bikker, C. Humblet, Escape from flatland: increasing saturation as an approach to improving clinical success, J. Med. Chem. 52 (2009) 6752-6756, doi:10.1021/jm901241e.

[50] M. Dagli, M. Er, T. Karakurt, A. Onaran, H. Alici, H. Tahtaci, Synthesis, characterization, antimicrobial evaluation, and computational investigation of 
substituted Imidazo[2,1-b][1,3,4] thiadiazole derivatives, ChemistrySelect 5 (38) (2020) 11753-11763, doi:10.1002/slct.202002821. 